\title{
Lithium in Unconsolidated Sediments and Plants of the Basin and Range Province, Southern California and Nevada
}

GEOLOGICAL SURVEY PROFESSIONAL PAPER 918

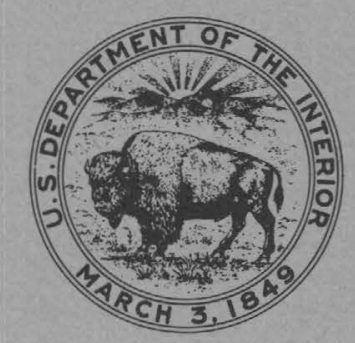





\section{Lithium in Unconsolidated Sediments and Plants of the Basin and Range Province, Southern California and Nevada}

By HELEN L. CANNON. THELMA F. HARMS, and J. C. HAMILTON

GEOLOGICAL SURVEY PROFESIONAL PAPER 918

A study of the accumulations of lithium in the evaporites, clays, freshwater limestones, waters, and vegetation of open and closed basins

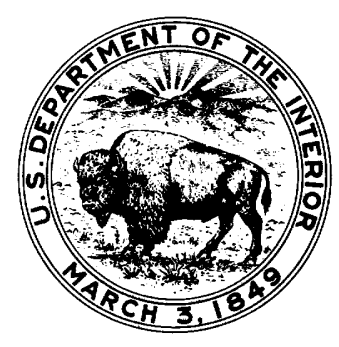




\title{
UNITED STATES DEPARTMENT OF THE INTERIOR
}

\section{GEOLOGICAL SURVEY}

\author{
V. E. McKelvey, Director
}

Library of Congress Cataloging in Publication Data

Cannon, Helen E. Leighton, 1911 -

Lithium in unconsolidated sediments and plants of the Basin and Range province, southern California and Nevada.

(Geological Survey Professional Paper 918)

Bibliography: p.

Supt. of Docs. No.: I 19.16:918

1. Lithium. 2. Sediments (Geology)-California. 3. Sediments (Geology)-Nevada. 4. Plants-Chemical analysis. 5. Water, Underground-California. 6. Water, Underground-Nevada.

I. Harms, Thelma F. II. Hamilton, J. C. III. Title: Lithium in unconsolidated sediments and plants of the Basin and Range province ... IV. Series: United States Geological Survey Professional Paper 918.

QE516.L5C36 553'.499 75-619074

For sale by the Superintendent of Documents, U.S. Government Printing Office

Washington, D.C. 20402

Stock Number 024-001-02213-3 


\section{CONTENTS}

Abstract

Introduction

Collection and treatment of samples .

Geography and ecology of the Basin and Range province

Geochemistry of lithium

Rocks..

Soils and sediments

Water.......

Vegetation

Lithium in the Basin and Range province

Hydrological relationships
Page

1

1 1

3

3

3

4

4

4

5

Lithium in the Basin and Range province-Con.

Lithium uptake by desert plants...................................... 6

Open basins discharged by underflow ............................... 7

Hydrologically closed basins....................................... 11

Death Valley ..................................................... 12

Amargosa Desert ..................................................... 14

Other closed basins.................................................. 16

Plant prospecting ........................................................ 19

Health aspects of lithium ............................................. 21

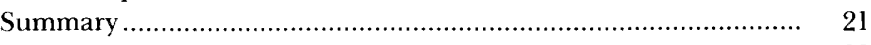

References cited ........................................................... 22

\section{ILLUSTRATIONS}

FIGURE 1. Map showing concentration of lithium in basin sediments, California and Nevada........

2. Graph showing relationship between lithium in plants and that in soil.

3-7. Photographs:

3. Crown of rush killed by hot-spring precipitate, Clayton Valley.

4. Precipitate of biogenetic origin occurring in place, Amargosa Desert

5. $\mathrm{CaCO}_{3}$ precipitate on organic detritus, Amargosa Desert

6. Cast of former root or stem structure, Amargosa Desert ......

7. Pickleweed (Allenrolfea) on salt mounds in Death Valley.........

\section{TABLES}

TABLE 1. Lithium, strontium, boron, and fluorine content in some waters of Nye County, Nev., and Inyo County, Calif., compared with 100 municipal water supplies in the United States.

2. Maximum lithium concentrations in some basins of Nevada and California

3. Plant species sampled in Nevada and California.

4. Lithium in plant groups of the Great Basin, California-Nevada

5. Maximum contents of lithium and sodium in some plants and basin soils

6. Percentage of lithium and associated ions in sediments and the ash of plants from open basins in Nevada and California

7. Percentage of lithium and associated ions in basin sediments, collected within 6 inches of the ground surface

8. Percentage of lithium and associated ions in sediments and the ash of plants from Death Valley, Calif......

9. Chemical constituents of some springs and wells in Amargosa Desert ....

10-12. Percentage of lithium and associated ions in sediments and the ash of plants from:

10. Amargosa Desert, Nevada and California

11. Three closed basins in which economic quantities of lithium occur..

12. Some other closed basins in Nevada and California 



\title{
LITHIUM IN UNCONSOLIDATED SEDIMENTS AND PLANTS OF THE BASIN AND RANGE PROVINGE, SOUTHERN CALIFORNIA AND NEVADA
}

\author{
By Helen L. Cannon, Thelma F. Harms, and J. C. Hamilton
}

\begin{abstract}
Geochemical and geobotanical sampling of 20 hydrologically closed and open basins in the southern part of the Basin and Range province shows contrasting lithium contents of their sediments, vegetation, and natural waters. These findings have significant economic and environmental implications. In hydrologically closed basins, where groundwater discharge is mainly by evapotranspiration, economic concentrations of lithium are of three types-as lithium chloride in evaporites and brines, in the crystal lattice of montmorillonitic clays, and in carbonate precipitates in hot-spring and lacustrine deposits. Along with potassium, boron, and halite, lithium compounds are precipitated at a late stage of evaporation. Sediments collected from low areas of closed basins contain 30-1,500 ppm lithium, whereas sediments from open, drained basins contain 20-150 ppm lithium.

Recycled concentrations occur in association with hot springs at the alluvium-playa contact, where lithium dissolved at depth is precipitated around hydrophytic plants and organic debris. The average lithium content of native vegetation sampled in closed basins is 100 times the content reported for average plants. The lithium content of halophytic vegetation is closely related to that of the soil, anomalous accumulations occurring in plants that also take up large concentrations of sodium chloride. Ground water contains 50 times more lithium than average municipal water supplies in the United States. Lithium is produced commercially from volcanic clays and, also, by brine evaporation in several closed basins; analysis of vegetation may furnish a means of prospecting for deep-seated lithium brines. Contents of as much as 3,000 ppm lithium were found in the ash of pickleweed (Allenrolfea) and in rushes rooted in hot springs. An average of $150 \mathrm{ppm}$ lithium in the ash and $25.8 \mathrm{ppm}$ in the dry weight of all plants that were collected in both closed and open arid basins is considerably higher than the average of $1.3 \mathrm{ppm}$ in dry weight reported for plants growing in a nonarid climate. The high lithium content in well waters and vegetation of closed basins is probably beneficial, rather than harmful, to animals and man.
\end{abstract}

\section{INTRODUCTION}

The geochemistry of lithium in sediments and its absorption by plants in the arid basins of the Basin and Range physiographic province were studied after a broad geochemical study had found large amounts of lithium in the native plants of the basins. The importance of concentrations of lithium in plants is twofold: first, the plants may be of value as indicators of lithium-rich brines at depth; and second, the uptake of lithium by concentrator species of forage or produce may be of significance nutritionally to livestock and man. Therefore, we studied the plant-soil relationships in closed basins that are discharged by evapotranspiration and in open basins that are discharged by underflow through permeable beds at considerable depths to lower basins. Plants and sediments were sampled in 20 basins of California and Nevada (fig. 1), as time permitted, during 1963-67. Plants and the sediments in which the plants grew were collected in each basin from the lowest and wettest part of the basin, and, locally, suites of samples were collected from several chemical zones in the basin. Generally, the plants were salt-tolerant species-phreatophytes in the closed basins and xerophytes in the open basins. The flora and deposits of springs were of particular interest. Analytical data on eight elements are reported here, together with available water analyses.

\section{COLLECTION AND TREATMENT OF SAMPLES}

Branch tips and leaves were collected from the larger shrubs, and the above-ground parts were sampled from herbaceous plants. The samples were not washed but were dried in paper sacks and analyzed in the U.S. Geological Survey laboratories in Denver, Colo. Soil samples were air-dried and then sifted through an 80 -mesh sieve. Plant samples were dried at $50^{\circ} \mathrm{C}$, ground in a Wiley mill, and ashed in a muffle furnace at $500^{\circ} \mathrm{C}$. Of the elements reported, magnesium and carbonate were analyzcd by rapid rock analysis; calcium, sodium, and potassium by atomic absorption; sulfate by a colorimetric method; fluorine by selective electrode; and boron by emission spectrograph. The lithium content of each sample was determined by two methods-semiquantitative spectrographic analysis (Myers and other, 1961) and atomic absorption method (Ward and others, 1969). Determinations by atomic absorption for lithium in the plants were made by leaching $100 \mathrm{mg}$ of ash in $2 \mathrm{ml}$ of $6 \mathrm{~N} \mathrm{HCl}$ and diluting the leachate to $25 \mathrm{ml}$ before atomizing. Lithium detection limits are $10 \mathrm{ppm}$ for the atomic absorption method and $100 \mathrm{ppm}$ for the 6-step spectrographic procedure, which appears to be more reproducible for higher values. Therefore, the reported low values were determined by atomic absorption and the high values by emission spectrograph. A 


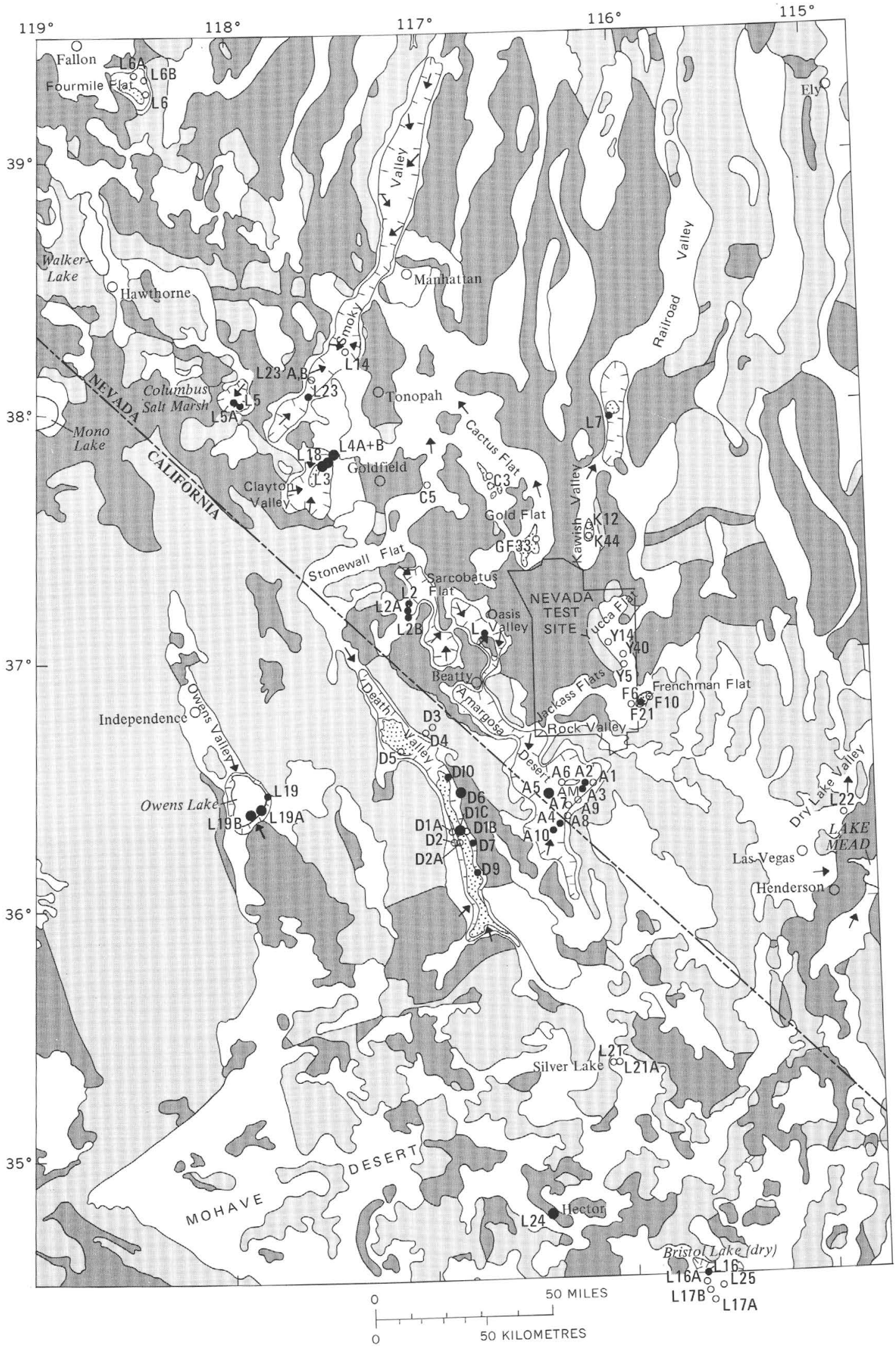

Ficulifor from Stose (1932). Map explanation is on facing page. 


\section{EXPLANATION}

\begin{tabular}{|c|c|}
\hline & Valley fill \\
\hline & Sedimentary rocks - Largely Paleozoic limestones \\
\hline & Igneous rocks - Largely volcanic tuffs \\
\hline$\pi$ & Closed basin discharged by evapotranspiration \\
\hline 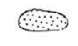 & Playa \\
\hline$\rightarrow$ & Direction of ground-water movement \\
\hline & $\begin{array}{l}\text { Lithium in sediment sample - In parts per million. Plants } \\
\text { were collected at all sample localities }\end{array}$ \\
\hline$\circ$ & $<100$ \\
\hline$\bullet$ & $100-300$ \\
\hline - & $>300$ \\
\hline$A M$ & Ash Meadows \\
\hline $\mathrm{C5}$ & Station number \\
\hline
\end{tabular}

spread in lithium values was noted in high-sodium plants that were analyzed by both methods. Probably sodium masks lithium in determinations by atomic absorption to some degree but enhances the lithium values on the spectrograph.

Also presented herein are analyses of waters sampled by U.S. Geological Survey hydrologists; the samples were filtered, acidified, and analyzed chemically and by emission spectrograph in the Denver laboratories.

The senior author collected the samples, assisted at various times by Thelma F. Harms, Margaret E. Hinkle, and Mary Strobell. Analyses by emission spectrograph and atomic absorption were made in U.S. Geological Survey laboratories, Denver, Colo., and by rapid-rock analysis in Washington, D.C. Analysts were as follows:

Chemical analysis of plants and soils: M. E. Hinkle, J. B. McHugh, K. W. Leong, J. H. Turner, T. F. Harms, Clara Papp

Spectrographic analysis of plants and soils: J. C. Hamilton, Barbara Tobin, J. L. Finley, H. G. Neiman, B. N. Lanthorn, E. L. Mosier, L. D. Forshey

Rapid-rock analysis: Paul Elmore, H. Smith, S. D. Botts, Lowell Artis, J. L. Glenn, Gillison Chloe, D. Taylor. Isaac Winograd, U.S. Geological Survey, provided helpful information concerning hydrological relationships.

\section{GEOGRAPHY AND ECOLOGY OF THE BASIN AND RANGE PROVINCE}

The Basin and Range province is characterized by a series of tilted fault blocks forming longitudinal, asymmetric ridges or mountains and broad intervening valleys. Weathering and erosion have lowered the mountain peaks and have filled the valleys with alluvium and products of volcanism to a depth of several thousand feet. The rocks range in age from Precambrian to Quaternary, but we are concerned here only with Pleistocene and Holocene basinfill sediments interbedded with volcanic tuffs and basaltic flows, and with the gravel fans that surround the basins. During the several pluvial periods of historic time, those basins in which the alluvium overlies relatively impervious rock formations were filled with lake water to a considerably higher elevation than exists today. Basins that are not hydrologically closed drain through the underlying Paleozoic sedimentary rocks to nearby lower basins. The lowest closed basin is Death Valley, whose surface is 280 feet $(85 \mathrm{~m})$ below sea level. Large concentrations of salts have built up in the closed basins by processes of evaporation and transpiration; the composition of the salts varies from basin to basin depending on the source of the water and the geology of the recharge area. The climate is generally arid, and so surface waters are apt to be ephemeral; the depth to ground water in open basins may be several hundred feet. Which plant species can live in a particular basin is controlled by altitude, by water conditions, the total salt content, and the tolerance of various species for particular ions that may occur in very high concentrations. Hunt (1966) described the salt zones of Death Valley as a central area of chlorides ringed successively by sulfide and carbonate zones. Each zone has a characteristic flora. The plants of greatest significance as indicators of soil conditions and as accumulators of ions are woody shrubs of the Upper and Lower Sonoran plant zones. Open basins are generally populated by xerophytic plants except at springs along the mountain-basin contact. Closed basins are populated by phreatophytes (deeprooted plants that depend on ground water for their water supply) on the basin proper and by xerophytes (plants adapted to dry conditions) on the peripheral gravel fans. Bare areas completely devoid of vegetation occur in the salt pan of Death Valley, playa muds of drier valleys, and on the steeper gravel fans. We sampled sediments of the bare areas in several basins as well as the soils in which plants were able to grow.

\section{GEOCHEMISTRY OF LITHIUM}

Lithium, a light metal, third in the periodic table, is widely distributed throughout the Earth's crust. It is used as a pottery glaze, as an absorbent in air conditioners, and as an ingredient of waterproof and high-temperature lubricants. The use of lithium in hydrogen bombs and of lithium flares accounts for some of the lithium that occurs at the Atomic Energy Commission's Nevada Test Site.

\section{ROCKS}

Lithium is concentrated in the silicates and aluminosilicates of acidic igneous rocks where it replaces magnesium, ferrous iron or aluminum; it is also present in pegmatite dikes where it forms independent lithium minerals, such as spodumene $\left(\mathrm{LiAlSi}_{2} \mathrm{O}_{6}\right)$, and the lithium 
micas, such as lepidolite, which are the main ores of the element. Averages for lithium in igneous rocks have ranged from 22 to 65 ppm (Parker, 1967). Averages for sediments, calculated by Rankama and Sahama (1950) from Strock (1936), are $17 \mathrm{ppm}$ in sandstones, $46 \mathrm{ppm}$ in shales, and $26 \mathrm{ppm}$ in limestones; contents of more than $100 \mathrm{ppm}$ are reported for iron ores.

In a Russian study of the geochemistry of lithium in the sedimentary cycle (Ronov and others, 1970), 21,000 samples were analyzed. Lithium was found to concentrate in clays in which it correlates most strongly with aluminum. The results of the Russian study show that the behavior of lithium is the weathering zone is not dependent on the petrographic type of the initial rock, on the initial lithium content, or on the geologic age of the crust but is determined by the sequence of stages or the physiochemical conditions of weathering: the metal is usually concentrated finally in kaolinite. Lithium entering clay minerals differs from sodium, potassium, rubidium, cesium, magnesium and calcium by being firmly bound during the formation of the clay minerals but by ultimately being released during the disintegration of clays to form laterite.

Tardy and others (1972) showed that the retention of lithium in clay minerals of weathering is weak and on the same order as the initial content of the rock $(<60 \mathrm{ppm})$; that the fixation of lithium is moderate in sedimentary clay minerals of detrital origin ( $<300 \mathrm{ppm})$; and that lithium is concentrated in new magnesium clay minerals formed under arid conditions in a carbonate or sulfate environment (as much as 6,000 ppm). The carbonates and sulfates that accompany the silicates, however, contain scant lithium (<30 ppm). Accordingly, the behavior of lithium can serve to distinguish in sediments the inherited clay minerals from newly formed clay minerals.

Lithium follows the pattern of magnesium and, in one mode of accumulation, is absorbed into the crystal structure of montmorillonite and illite (Mason, 1952). Lithium is not in an exchangeable site but is probably in the octahedral layer, substituting for magnesium (R. A. Sheppard and H. C. Starkey, written commun., 1972).

A second mode of lithium accumulation is in salt lagoons or basins where contents of lithium correlate negatively with those of aluminum but positively with those of magnesium, sulfate, and chloride; large concentrations of lithium occur in these evaporative basins (Ronov and others, 1970). Lithium not only is very soluble but is most easily displaced by ion exchange of all the cations and, hence, is a very mobile element that moves readily into and out of waters and sediments (Bear, 1964). In an evaporative basin, lithium may remain in solution until a late stage and then be precipitated along with sodium, potassium, and boron in the chloride and sulfate zones (Stewart, 1963). In several basins in the Western
United States, lithium and potassium are commercially produced by evaporating the brines.

\section{SOILS AND SEDIMENTS}

Swaine (1955) reported 8 to $400 \mathrm{ppm}$ lithium in soils. Steinkoenig (1915) reported 10 to $100 \mathrm{ppm}$ in soil and 20 to $70 \mathrm{ppm}$ in subsoil from 19 soils in 6 different areas of the United States. Recent U.S. Geological Survey studies in Missouri show a geometric mean of $21 \mathrm{ppm}$ lithium for that State.

In the arid Basin and Range province, lithium is concentrated in hydrologically closed basins but not in open basins. In closed basins, soluble salts move upward to the ground surface, where they are further concentrated by evaporation and plant transpiration; in open basins the salts move downward to the ground-water table at depth and then laterally to a lower basin. Surface sediments (exclusive of alluvium) collected in our study contained 30 to $2,000 \mathrm{ppm}$ lithium (median, $150 \mathrm{ppm}$ ) in 12 closed basins and 30 to $150 \mathrm{ppm}$ (median, $50 \mathrm{ppm}$ ) in 8 open basins.

\section{WATER}

The lithium content of fresh water is considerably less than that of sea water $(0.1 \mathrm{ppm})$, because lithium chloride is highly soluble and remains in solution in sea water more or less indefinitely. A median of $2 \mathrm{mg} / \mathrm{l}(0.002 \mathrm{ppm})$ lithium was stated by Durfor and Becker (1964) for municipal water supplies; some of this lithium may be sorbed by suspended clay. Thermal waters commonly contain large quantities of lithium leached as lithium chloride from rocks penetrated by the waters (Rankama and Sahama, 1950).

\section{VEGETATION}

Lithium is not known to be an essential plant nutrient, but its presence in all plants and its effect on plant growth suggests that lithium is necessary for plant growth and development. It exerts both stimulating and retarding effects on plant growth, depending on the concentration and on the plant species. According to Evans and Sorger (1966) at least one enzyme from a halophile is activated by sodium and lithium but not by potassium or rubidium. Those enzymes that are activated by potassium are not activated by lithium. After analyzing 680 plants from 68 families, Bertrand $(1952 ; 1959)$ reported an average of 0.85 $\mathrm{ppm}$ in the dry weight of Monocotyledons and $1.3 \mathrm{ppm}$ in Dicotyledons. Averages by Bertrand for some families are given in table 4. Robinson and others (1917) found an average of $0.3-0.42 \mathrm{ppm}$ in dry weight of various classes of vegetation.

Borovik-Romanova (1965) analyzed 138 plants from 8 soil types by emission spectrography, using potassium chloride as buffer. She found that plants generally have an 
average content of 0.15 to $0.3 \mathrm{ppm}$, but plants rooted in saline soils contain 2 to 10 times that level.

Lithium accumulates first in the root and then moves into the older leaves where it becomes immobilized (Kent, 1941). High values were found in the dry weight of crops irrigated with water containing 0.1 to $0.2 \mathrm{ppm}$ lithium; more lithium was concentrated in the leaves than in the roots (Bradford, 1966).

Vlasiuk and Okhrimenko (1967) experimented with various increments of lithium to determine effects on growth, development, and productivity of tomatoes and potatoes. The lithium was introduced as lithium sulfate in amounts of $0.1,1.0,2.0,3.0,10.0$, and $30.0 \mathrm{ppm}$, and the experiments were repeated 6 times. Curves plotted on doses versus product weight are bimodal, with two optimal values-for tomatoes, 0.1 and $2.0 \mathrm{ppm}$; and for potatoes, 0.1 and $5.0 \mathrm{ppm}$. The reason for these double optima is unknown. In 1969 the same authors reported that lithium stimulates the photochemical activity of chloroplasts and chlorophyll content in tomato and pepper leaves, with a consequent increase in the yield. According to BorovikRomanova (1965), lithium forms part of the protein fraction of the leaf, and lithium ions substantially stimulate the metabolism of protein and carbohydrate in the plant.

The amounts of lithium that stimulate growth and amounts that produce toxicity symptoms depend upon the tolerance of the particular species and the form of salt administered. Puccini (1957) reported that several lithium salts improved the growth of carnations, whereas lithium carbonate was toxic. Voelcker (1912) found any lithium salt to be stimulating to wheat in amounts of less than 20 ppm but to be toxic in amounts greater than $30 \mathrm{ppm}$ in the soil; lithium nitrate was found to be the most toxic salt but nevertheless the most stimulating salt to growth when present in amounts less than $10 \mathrm{ppm}$. Plant species vary widely in their tolerance. Citrus trees are sensitive to lithium, and toxicity symptoms develop in citrus growing in California in areas where the lithium content of the soil is only $12 \mathrm{ppm}$ (Bradford, 1966). Lithium contents in the tree reach $40 \mathrm{ppm}$ dry weight or perhaps $400 \mathrm{ppm}$ in the ash. Toxicity in avocado seedlings in pot culture was produced by the addition of $16 \mathrm{ppm}$ lithium. Symptoms include necrotic spots in the interveinal leaf tissue and eventual browning and curling of the leaf margins. Meristem damage occurred in root tips of corn exposed to high lithium concentrations (Edwards, 1941).

Some plants, on the other hand, tolerate large amounts of lithium, and growth is stimulated when the soil contains considerable concentrations. The best-known such plant is tobacco, a member of the Solanaceae. Headden (1921), in plot experiments, found 496 ppm lithium oxide in the ash (or $\pm 40 \mathrm{ppm}$ in the dry weight) of Nicotiana affinis and $108 \mathrm{ppm}$ in Nicotiana tobacum but only a trace in alfalfa grown in the same soil. A maximum value of
4,400 ppm (or $\pm 750 \mathrm{ppm}$ in the dry weight) was reported by Strock (1936) in tobacco ash. Borovik-Romanova (1965) found species of Thalictrum, Adonis, Cirsium, Nicotiana, Salsola, Solanum, Ranunculus, Lycium, Atropa belladonna, and Datura stramonium to accumulate lithium to an unusually large degree. She noted that the lithium content is highest in samples with high alkaloid contents, which also varies with locality and growing season. In recent years, lithium compounds have often been used in organic synthesis, and they may participate in the biosynthesis of alkaloids. Vinogradov (1952) described a lithium flora which includes Thalictrum (Ranunculaceae). Linstow (1929) reported Lycium barbarum of the Solanaceae to be a lithium indicator. Lycium, which is used in making jelly, was sampled on lands inhabited by the Pima Indians in Arizona; it contained 1,120 ppm lithium in the dry weight of the plant (Sievers and Cannon, 1974).

\section{LITHIUM IN BASIN AND RANGE PROVINCE \\ HYDROLOGICAL RELATIONSHIPS}

Two distinct types of basins occur in the Basin and Range province: hydrologically closed basins, in which the ground water is only discharged by evapotranspiration, and hydrologically open basins, in which the ground water is discharged by subsurface drainage through underlying sedimentary formations into a lower basin. Topography and surface drainage patterns in open basins do not necessarily coincide with the directions of ground-water movement. The Ash Meadows basin in the Amargosa Desert, for instance, drains several intermontane basins, all of which are hydrologically connected. The connection is effected by movement of ground water through the Paleozoic carbonate rocks that underlie the valleys at considerable depth (Winograd, 1962). The thousands of feet of fill in a closed basin act as an immense underground reservoir, constantly becoming more concentrated with salts as water is lost through evaporation at the surface and through transpiration by plants.

In a closed basin the composition of solutes depends largely on the reaction of natural waters with the particular lithologic units underlying that basin and occurring in its area of recharge. The composition is dependent on the simple solution of readily soluble compounds, as might occur in preexisting salt beds, and on hydrolysis of various silicate minerals, depending on their relative solubility (Jones, 1966). The end product of weathering in the Basin and Range province is generally montmorillonite and carbonates except that in basins fed by waters draining extensive mineralized areas sulfates predominate. Sodium bicarbonate waters are common in volcanic areas, and calcium-magnesium carbonate waters are common in areas 
of limestones. Mixed waters may have originated in tuffs and then been altered by traveling through limestones, or the sequence may be the reverse (Eakin and others, 1963). Secondary influences on the solute composition are concentration by evaporation and concentration by organic respiration and decay (Jones, 1966). The evaporative process involves a "continuous precipitation of salts in concentric zones from the edge inward according to their relative solubility: alkali-earth carbonates, then sulfates, then chlorides at the center." The chemical zonation of sediments and the typical plant species that are able to grow on each zone (generally identified by anion as carbonate, sulfate, and chiloride zones) were studied by C. B. Hunt (1966; Hunt and others, 1966) in Death Valley, where he made on-site analyses of sediments and plants.

Lithium is reported to remain in solution until a late stage and to be precipitated with potassium and boron in the chloride zone (Stewart, 1963). Our sampling in Death Valley shows high values for lithium in both the sulfate and chloride zones; and Lombardi's (1963) analyses of springs in Saline Valley (west of Death Valley) show a similar concentration of lithium in high-sulfate water. Lombardi noted that in transit lithium is rapidly absorbed by clay in suspension. For example, the water of Vega Springs, Saline Valley, loses 98 percent of its lithium in flowing 2 miles $(3.2 \mathrm{~km})$ from spring to playa.

Lithium also is concentrated to a considerable degree in lacustrine montmorillonite clays of closed basins whose recharge is from volcanic rocks.

The amount of lithium concentrated in the brines from a large recharge area is considerable; a maximum of 1.62 percent lithium was found in the dried residue of Owens Lake water (Gale, 1915). The extraction of lithium, as well as potassium, from these large closed-basin reservoirs of brine is economically feasible; lithium chloride is currently being extracted from brines in several basins in Nevada and California.

Lithium concentrations in wells and springs are greater in chloride and sulfate waters than in bicarbonate waters and are significantly greater in closed basins than in open basins. Contents in springs and wells in southern Nevada, reported by B. P. Robinson and W. A. Beetam (written commun., 1965), Pistrang and Kunkel (1958), and Eakin and others (1963), range from $0.00 \mathrm{ppm}$ lithium to 0.3 $\mathrm{ppm}$, or $300 \mu \mathrm{g} / 1$ (table 1). Eighteen water samples from Amargosa Desert, a discharge area for several basins to the north, had a median lithium value of $105 \mu \mathrm{g} / \mathrm{l}, 50$ times the median of 100 major city water supplies in the United States.

The contents of lithium and associated ions in basin sediments that we sampled are given in table 2 . We conclude, as did the Russian scientists, that lithium is concentrated in residual chloride-sulfate brines of evaporative basins and also in evaporative lake clays close to volcanics.

\section{LITHIUM UPTAKE BY DESERT PLANTS}

Plants and soils were collected in relatively low areas of 20 basins in Nevada and California to study the uptake of lithium by salt-tolerant species (table 3 ).

Our analyses indicate (table 4) that native plants in the arid basins of the Western United States absorb much more lithium than do native plants in humid areas (Bertrand, 1952, 1959; Robinson and others, (1917). For the arid-basin samples, the median lithium content for 68 samples of dicotyledons is $150 \mathrm{ppm}$ in the ash or $22.8 \mathrm{ppm}$ in the dry weight, as compared with an average of $1.3 \mathrm{ppm}$ in dicotyledons collected by Bertrand. A median content of 27 ppm lithium in dry weight of 47 samples of Chenopodiaceae from our desert collections is markedly higher than the average of $3.8 \mathrm{ppm}$ found in Chenopodiaceae by Bertrand; except for Atriplex polycarpa, the median is higher (in lithium) than for plants sampled at the Nevada Test Site and Mohave Desert by Wallace, Romney, and Hale (1973). They found as much as 111 ppm lithium in the dry weight of Atriplex polycarpa and $176 \mathrm{ppm}$ in Lycium andersoni in Rock Valley, which is hydrologically an open valley but which contains a

\footnotetext{
TABLE 1.-Lithium, strontium, boron, and fluorine content $(\mu / l, p p b)$ in some waters of Nye County, Nev., and Inyo County, Calif., compared with 100 municipal water supplies in the United States
}

[Data on municipal water supplies from Durfor and Becker (1964); data on Nevada Test Site and Amargosa Desert from B. P. Robinson and W. A. Beetam (written commun., 1965). ND. not detected]

\begin{tabular}{|c|c|c|c|c|c|c|}
\hline \multirow{4}{*}{ 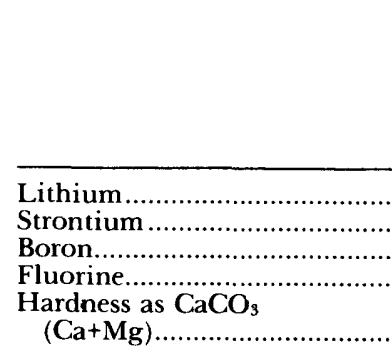 } & \multicolumn{2}{|c|}{$\begin{array}{l}\text { Water supply, } \\
100 \text { major U.S. } \\
\text { cities }\end{array}$} & \multicolumn{2}{|c|}{$\begin{array}{l}\text { Open basins, } \\
\text { Nevada Test Site } \\
\text { (8 wells) }\end{array}$} & \multicolumn{2}{|c|}{$\begin{array}{l}\text { Closed basins, } \\
\text { Amargosa Desert } \\
\text { (18 springs, wells) }\end{array}$} \\
\hline & $\begin{array}{r}\text { Median } \\
2\end{array}$ & Range & $\begin{array}{r}\text { Median } \\
20\end{array}$ & Range & $\begin{array}{r}\text { Median } \\
105\end{array}$ & Range \\
\hline & $\begin{array}{r}2 \\
110 \\
31 \\
400\end{array}$ & $\begin{array}{rr}\text { ND- } & 170 \\
2.2- & 1,200 \\
2.5- & 590 \\
0- & 7,000\end{array}$ & $\begin{array}{r}20 \\
40 \\
180 \\
1,000\end{array}$ & $\begin{array}{rr}13- & 46 \\
32- & 160 \\
110- & 280 \\
500- & 2,400\end{array}$ & $\begin{array}{r}105 \\
800 \\
420 \\
2,100\end{array}$ & $\begin{array}{rr}0- & 300 \\
500- & 7,700 \\
90- & 2,800 \\
700- & 7,000\end{array}$ \\
\hline & 90,000 & $0-738.000$ & 45,000 & $8,000-116,000$ & 119.000 & $26,000-482,000$ \\
\hline
\end{tabular}


TABLE 2.-Maximum lithium concentrations (percent) in some basins of Nevada and California

[Localities are shown in fig. 1]

\begin{tabular}{|c|c|c|}
\hline Area & $\begin{array}{r}\text { Maximum } \\
\text { in sedi }\end{array}$ & $\begin{array}{l}\text { thium } \\
\text { thent or } \\
\text { aporite }\end{array}$ \\
\hline \multicolumn{3}{|c|}{ Closed basins, discharged by evapotranspiration } \\
\hline Amargosa Desert, Nye County, Nev., and Inyo Co & & 0.15 \\
\hline Big Smoky Valley, Nye County, Nev ....................... & ........ & .01 \\
\hline Bristol Lake, San Bernardino County, Calif............ & .................. & .03 \\
\hline Clayton Valley, Esmeralda County, Nev.................. & .................... & .05 \\
\hline \multicolumn{2}{|c|}{ Columbus Salt Marsh, Esmeralda County, Nev } & .023 \\
\hline \multicolumn{2}{|c|}{ 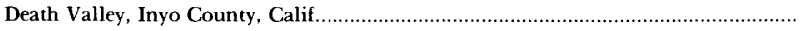 } & .03 \\
\hline \multicolumn{2}{|c|}{ Fourmile Flat, Churchill County, Nev } & .007 \\
\hline \multicolumn{2}{|c|}{ 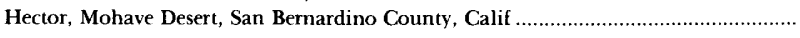 } & .20 \\
\hline \multicolumn{2}{|c|}{ Oasis Valley, Nye County, Nev } & .015 \\
\hline \multicolumn{2}{|c|}{ 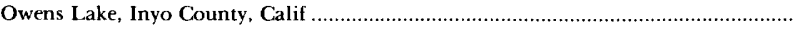 } & .08 \\
\hline \multicolumn{2}{|c|}{ 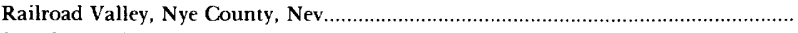 } & .015 \\
\hline \multicolumn{2}{|c|}{ Sarcobatus Flat, Nye County, Nev } & .03 \\
\hline Median & & 0.03 \\
\hline
\end{tabular}

Open basins, discharged by underflow

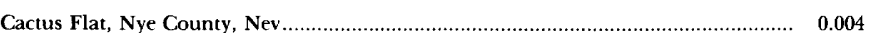

Dry Lake Valley, Clark County, Nev ......................................................................... . .005

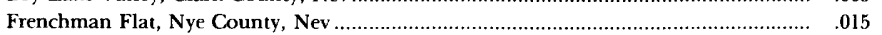

Gold Flat, Nye County, Nev ............................................................................

Kawich Valley, Nye County, Nev...........................................................................

Silver Lake, San Bernardino County, Calif ....

Stonewall Flat, Nye County, Nev.

Median.........

sodium-calcium sulfate type of water unusual to the region. The source of the water is a sequence of volcanics (Schoff and Moore, 1964).

The highest lithium contents in plant ash were found in Juncus cooperi, a rush, and Allenrolfea occidentalis, pickleweed, rooted in a hot spring on the east side of Clayton Valley. Most species that contained more than 400 ppm lithium in the ash are sodium chloride accumulators in which sodium may be absorbed and used in place of potassium. For certain species of Atriplex, sodium is an essential element (Brownell, 1965). The sodium plus potassium content in the plant appears to remain constant for the genus, but the sodium:potassium ratio varies with the species. Except for the hydrophytes Juncus and Anemopsis, the high-lithium plants are all halophytes from the Chenopodiaceae family (table 5 ). The relationship between the uptake of sodium and lithium in all the plants collected is as follows:

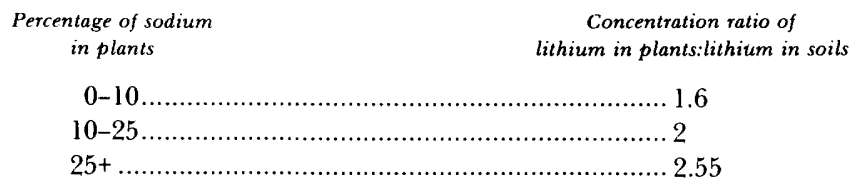

The lithium content of native plants correlates well with the lithium content of the soils in which the plants were rooted (fig. 2) The correlation is better than might
TABLE 3.-Plant species sampled in Nevada and California

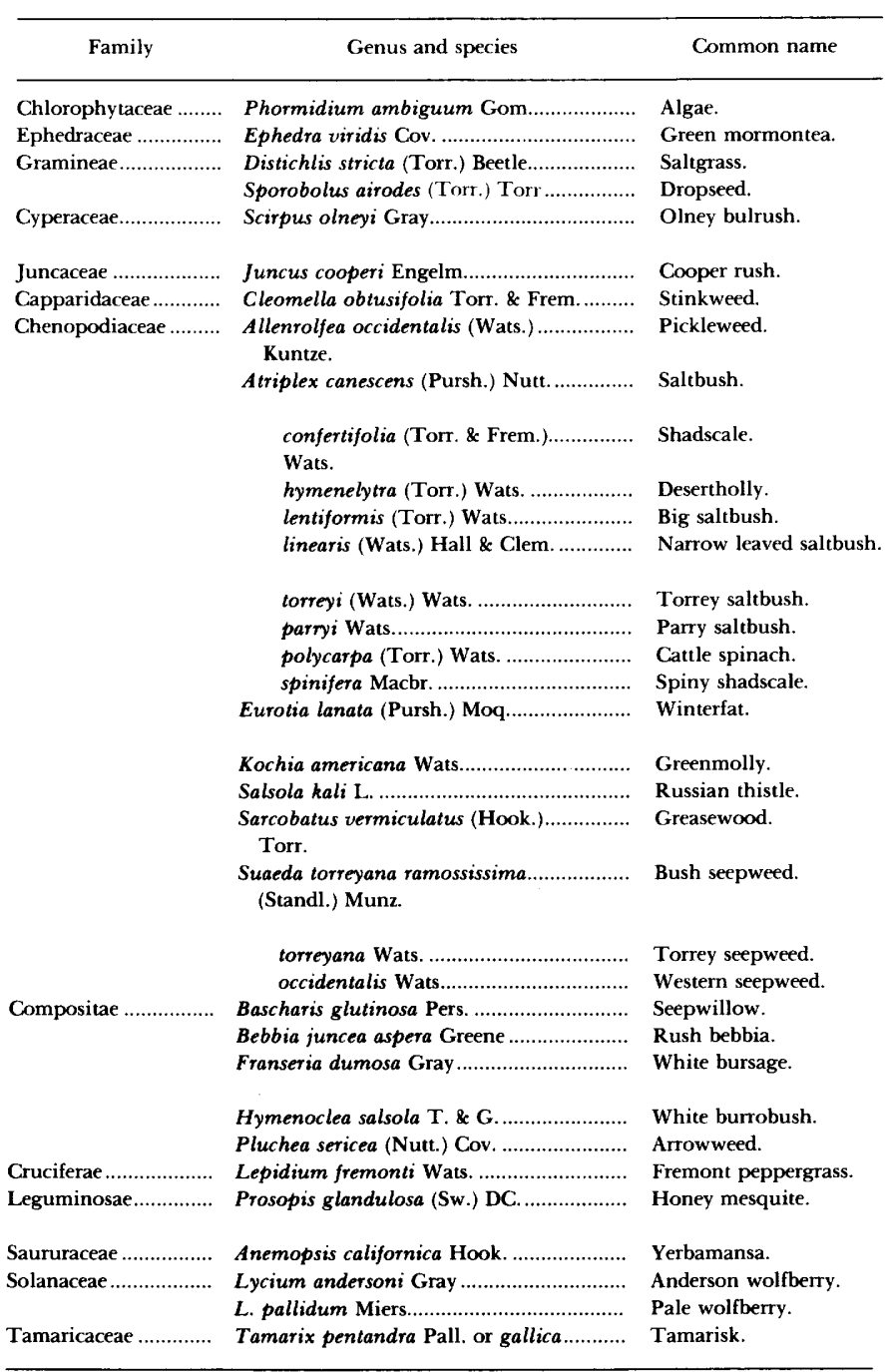

have been expected, inasmuch as only the top 5 inches of soil or evaporite were sampled, and the roots of the larger phreatophytic shrubs may extend to considerable depths and actually reach a deeper zone of chemical precipitate. The concentration ratio of lithium in plant to lithium in soil is greatly increased for sodium accumulator plants. A maximum concentration ratio of 10 occurred in samples of pickleweed and desertholly. Commonly, the ratio is also increased where the soils contain less than $100 \mathrm{ppm}$ lithium. A plot of lithium in plants against calcium in soils shows no pattern that confirms an interference in uptake of lithium by the presence of high calcium as Epstein had reported (1960). A more detailed discussion of the distribution of lithium in soils and plants, by area, follows.

\section{OPEN BASINS DISCHARGED BY UNDERFLOW}

Many basins of the Basin and Range province are discharged by underflow and have been filled by clastic 
TABLE 4.-Lithium content (parts per million) in plant groups of the Great Basin, California-Nevada

[Comparative data on analyses of plants growing in France from Bertrand (1959). P, phreatophyte; Ha, halophyte; Hy, hydrophyte; X, xerophyte; ND, not detected; <, less than; $\sim$, approximately]

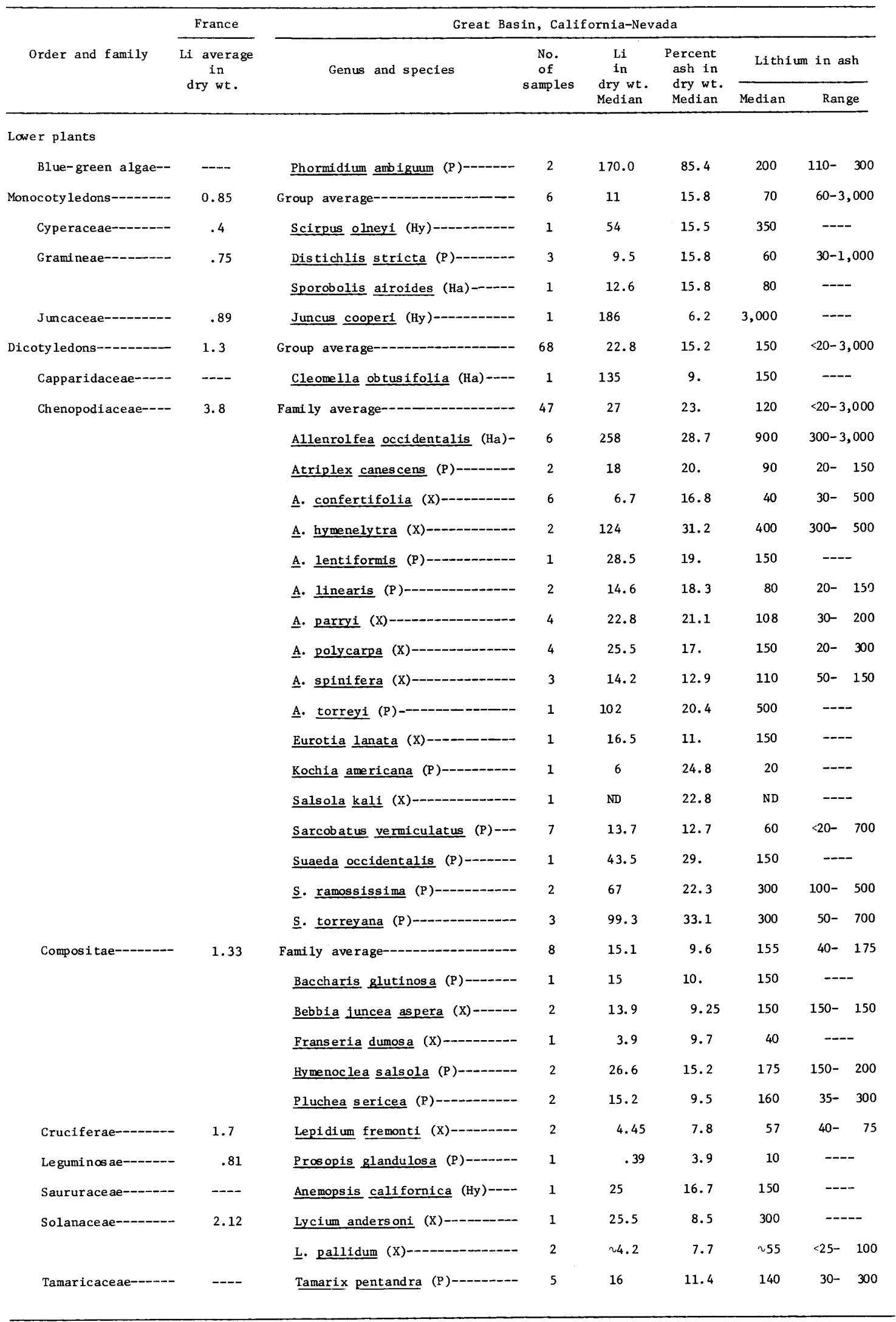


TABLE 5.-Maximum contents of lithium and sodium in some plants and basin soils [Analysts: Thelma F. Harms, B. N. Lanthorn]

\begin{tabular}{|c|c|c|c|c|c|c|c|c|c|}
\hline & \multicolumn{5}{|c|}{ Plant } & \multicolumn{3}{|c|}{ Soil } & \multirow{3}{*}{$\begin{array}{c}\text { Plant ash } \\
\text { to soil } \\
\text { lithium } \\
\text { ratio }\end{array}$} \\
\hline & \multirow{2}{*}{$\begin{array}{l}\text { Lab. } \\
\text { No. }\end{array}$} & \multicolumn{2}{|c|}{$\begin{array}{c}\mathrm{Na} \\
\text { (percent) }\end{array}$} & \multicolumn{2}{|c|}{$\begin{array}{c}\mathrm{Li} \\
(\mathrm{ppm})\end{array}$} & \multirow{2}{*}{$\begin{array}{l}\text { Lab. } \\
\text { No. }\end{array}$} & \multirow{2}{*}{$\begin{array}{c}\text { Na } \\
\text { (percent) }\end{array}$} & \multirow{2}{*}{$\begin{array}{c}\begin{array}{c}\mathbf{L i} \\
(\mathrm{ppm})\end{array} \\
\begin{array}{c}\text { Dry } \\
\text { weight }\end{array}\end{array}$} & \\
\hline & & Ash & $\begin{array}{c}\text { Dry } \\
\text { weight }\end{array}$ & Ash & $\begin{array}{c}\text { Dry } \\
\text { weight }\end{array}$ & & & & \\
\hline Allenrolfea occidentalis (pickleweed)............ & D413057 & 29 & 10.1 & 3,000 & 1050 & D413102 & 2.1 & 300 & 10 \\
\hline Juncus cooperi (rush) ................................ & D408136 & 22 & 1.4 & 3,000 & 185 & D408181W & 3.0 & 500 & 6 \\
\hline 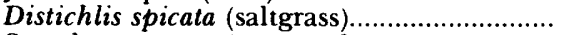 & D413091 & 18 & 2.7 & 1,000 & 150 & D413098 & 2.0 & 120 & 8.3 \\
\hline Suaeda torreyana (seepweed) ......................... & D413054 & 26 & 6.2 & 700 & 168 & D413098 & 2.0 & 120 & 5.8 \\
\hline Sarcobatus vermiculatus (greasewood).......... & D408134 & 23 & 2.9 & 700 & 90 & D408177W & 4.7 & 300 & 2.3 \\
\hline Atriplex torreyi (Torrey's saltbush) ............... & D411534 & 26 & 5.3 & 500 & 100 & D413125 & 1.4 & 70 & 5.0 \\
\hline 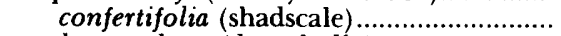 & D405826 & 20 & 3.5 & 500 & 90 & D405847 & 3.0 & 70 & 7.1 \\
\hline hymenelytra (desertholly) ........................ & D412065 & 23 & 6.9 & 500 & 150 & D412058 & 1.3 & 50 & 10 \\
\hline
\end{tabular}

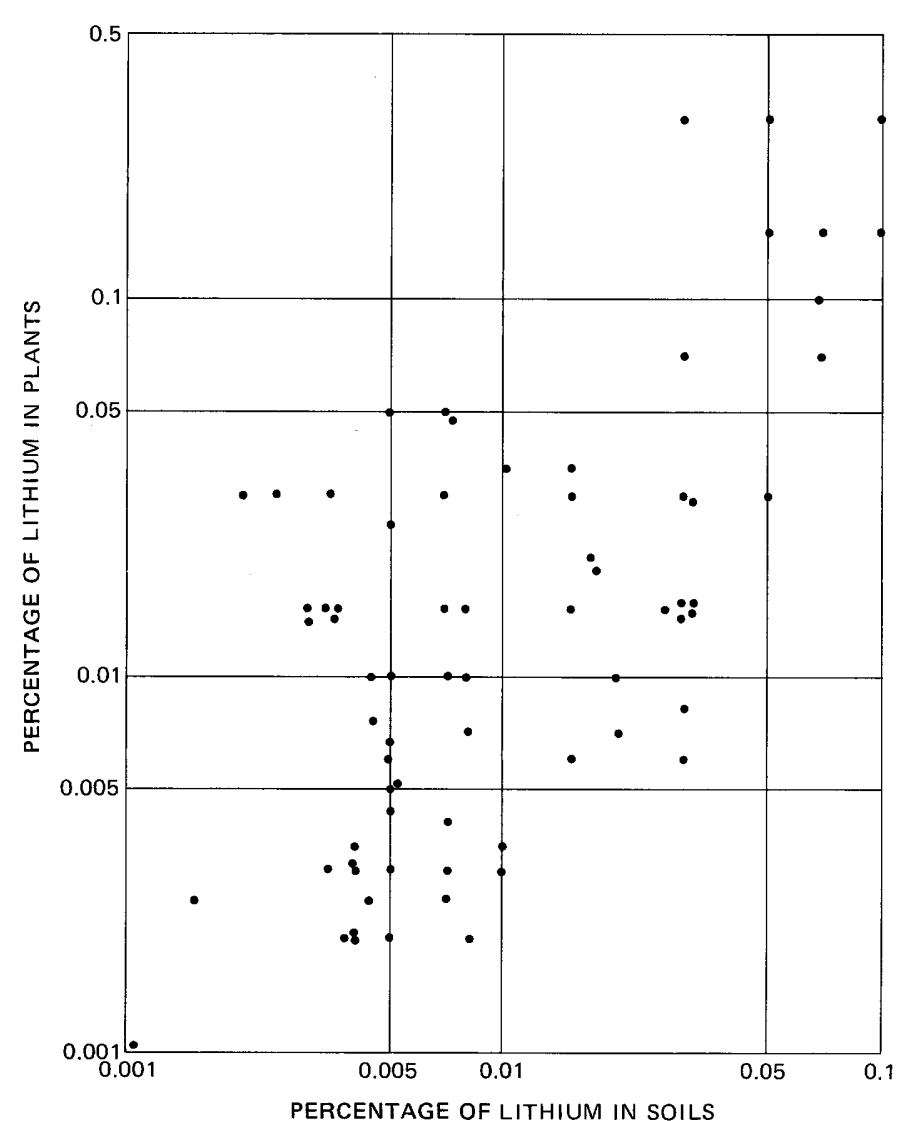

FIGURE 2.-Relationship between lithium in plants and that in soil.

materials of variable texture deposited from intermittent streams during torrential storms. The coarser materials are deposited on the higher parts of alluvial fans, and the fine silt and clay eventually reach the basin, where they are deposited in a thin layer over the playa as the water evaporates. Caliche, which is distributed in this type of basin through hundreds of feet of alluvium above the water table, probably is flushed out of the near-surface soils and is precipitated from surface water as it percolates downward through the beds; this contrasts with the upward capillary flow and near-surface deposition of caliche in closed basins (Johnson and Hibbard, 1957). In northern
Yucca Flat, for instance, there is no caliche in the top 18 feet $(5.5 \mathrm{~m})$.

Alluvial basins discharged by underflow are not large reservoirs of water that are constantly being evaporated to brines; rather, they are undergoing a flushing action that prevents the buildup of salts. These basins can support lakes only if the underflow is considerably less than the recharge or if the sedimentation is such as to form a perched water table. Some such situation must have existed in the pluvial period in Gold Flat and Dry Lake Valley, as evidenced by old beaches, although the present ground-water table is several hundred feet deep (Eakin, 1963). Perched water appears to be close to the surface on the southern part of the Gold Flat playa, and many phreatophytes grow there. The soil contains 5.4 percent water-soluble sulfate, and a white efflorescence of salts coats the surface of the ground.

Analytical data for eight open basins are given in table 6; the sample localities are shown in figure 1 .

The lithium content of sediments collected from hydrologically open basins was generally low, ranging from not detected to $150 \mathrm{ppm}$, with a median of $50 \mathrm{ppm}$ and a mean of $54 \mathrm{ppm}$ (table 6). The playas of open basins are largely composed of calcium-magnesium carbonate and clay; the surrounding sediments are sandy alluvium containing considerable caliche. The magnesium:lithium ratio is high. Boron contents are similar to those of lithium and range from 20 to $70 \mathrm{ppm}$. Probably no lithium or boron deposits of economic value can be expected in basins drained by underflow.

A maximum of $500 \mathrm{ppm}$ lithium was found in a sample of Atriplex confertifolia from Stonewall Flat. This high lithium content, however, may be caused by contamination because neither the soil nor Lepidium collected at the same station contained much lithium; all three materials were collected near ground zero of a surface plutonium release which may have been accompanied by lithium flares. The 20 plant samples collected in open basins had a median content of $30 \mathrm{ppm}$ lithium in the ash or $4.8 \mathrm{ppm}$ lithium in the dry weight. 
TABLE 6.-Percentage of lithium and associated ions in sediments and the ash of plants from open basins in Nevada and California [Stations shown in fig. I. Analysts are named in introduction. N, not detected; Ma, element present in major quantity; X, xerophyte; P, phreatophyte; M, mesophyte; WSS, water-soluble salts The soil in which the sampled plant grew is listed directly below each plant]

\begin{tabular}{|c|c|c|c|c|c|c|c|c|c|c|c|c|c|c|c|c|c|c|c|}
\hline \multirow[t]{2}{*}{$\begin{array}{l}\text { Sta- } \\
\text { tion } \\
\text { No. }\end{array}$} & \multirow[t]{2}{*}{ Sample } & \multirow[t]{2}{*}{$\begin{array}{l}\text { Lab. } \\
\text { No- } \\
\text { (D-) }\end{array}$} & \multirow{2}{*}{\multicolumn{2}{|c|}{$\frac{\text { Ash wSS }}{\text { (percent) }}$}} & \multicolumn{2}{|c|}{ Lithium } & \multicolumn{2}{|c|}{ Magnesium } & \multicolumn{2}{|c|}{ Calcium } & \multicolumn{2}{|c|}{ Sodium } & \multicolumn{2}{|c|}{ Potassium } & \multicolumn{2}{|c|}{ Boron } & \multirow{2}{*}{$\begin{array}{c}\begin{array}{c}\text { Carbo- } \\
\text { nate } \\
\left.\text { (as } \mathrm{CO}_{2}\right)\end{array} \\
\text { Soil }\end{array}$} & \multicolumn{2}{|c|}{$\begin{array}{l}\text { Sulfate } \\
\text { (water- } \\
\text { soluble) }\end{array}$} \\
\hline & & & & & Plant & Soi1 & Plant & Soil & P1ant & Soil & Plant & Soil & P1ant & Soil & Plant & Soil & & Plant & : Sol1 \\
\hline \multicolumn{20}{|c|}{ Frenchman Flat-- $\mathrm{NaHCO}_{3}$ ground water at depth $623-1,103 \mathrm{ft}(190-336 \mathrm{~m})$} \\
\hline \multirow[t]{3}{*}{ F6 } & $\begin{array}{l}\text { Lycium pallidium } \\
\text { (X)- }\end{array}$ & 403492 & 5.8 & 3--- & 0.01 & ---- & 5.0 & ---- & 28 & $\cdots$ & 1.6 & ---- & 12 & ---- & $-\cdots$ & ------ & $-\cdots$ & 0.19 & -.-- \\
\hline & $\begin{array}{l}\text { Sandy clay west } \\
\text { of playa------ } \\
\text { Lycium pallidum }\end{array}$ & 403201 & --- & 0.30 & ----- & $\mathrm{N}$ & ----- & 1.4 & $\cdots$ & 4.0 & --- & 1.7 & $\cdots$ & 2.9 & 0.01 & ------ & 2.4 & ----- & $<0.01$ \\
\hline & $\begin{array}{l}\text { Lyerum pallidum } \\
(\mathrm{x})^{1} \text { - } \\
\text { p1aya clay---- }\end{array}$ & $\begin{array}{l}412496 \\
412501\end{array}$ & $\begin{array}{r}9.5 \\
-\end{array}$ & --. & \begin{tabular}{l}
$<.002$ \\
-0. \\
\hdashline..
\end{tabular} & 0.005 & $\begin{array}{r}1.5 \\
---\end{array}$ & ---- & 33 & $-\cdots .9$ & $\begin{array}{l}.6 \\
--.-\end{array}$ &.--95 & $\begin{array}{c}5.1 \\
----\end{array}$ & --- & ----- & $<0.002$ & -- & ----- & $-\cdots$ \\
\hline \multirow[t]{4}{*}{ F10 } & $\begin{array}{l}\text { Playa clay on } \\
\text { east side (no }\end{array}$ & & & & & & & & & & & & & & & & & & --.- \\
\hline & $\begin{array}{l}\text { vegetation)---- } \\
\text { Atriplex lineuris }\end{array}$ & 411562 & --- & $\cdots$ & ----- & .003 & ---- & 3.2 & $\cdots$ & 10 & -..-- & .85 & $\cdots$ & 2.0 & ----- & $<.002$ & ---- & ----- & --- \\
\hline & $\begin{array}{l}\text { (P)- } \\
\text { A. spinifera (X)- } \\
\text { Kochia americana }\end{array}$ & $\begin{array}{l}413078 \\
413079\end{array}$ & $\begin{array}{l}16 \\
21\end{array}$ & --- & $\begin{array}{l}.002 \\
.002\end{array}$ & ----- & $\begin{array}{l}7.0 \\
5.0\end{array}$ & --- & ${ }_{12}^{9.0}$ & --- & $10^{.28}$ & --- & $\begin{array}{l}25 \\
17\end{array}$ & ---- & $\begin{array}{l}.015 \\
.02\end{array}$ & --- & ---- & $\begin{array}{l}.40 \\
.92\end{array}$ & --- \\
\hline & $\begin{array}{l}\text { (P)-clay with } \\
\text { Playa clay }\end{array}$ & 413080 & 16 & ---- & .003 & $-\cdots$ & 7.0 & --- & 11 & $\cdots$ & 11 & $-\cdots$ & 16 & --- & .07 & ----- & $-\cdots-$ & .33 & --- \\
\hline \multirow{2}{*}{ F21 } & $\begin{array}{l}\text { plants--- } \\
\text { Playa clay (no }\end{array}$ & 413115 & --- & $\cdots$ & $-\cdots$ & .004 & ---- & 3.0 & ----- & 10 & ----- & .8 & ----- & 1.9 & ----- & .005 & --- & $\cdots$ & .03 \\
\hline & vegetation)---- & 406182 & --- & .13 & ----- & .015 & ----- & 3.1 & $-\cdots$ & 7.8 & ----- & .53 & $-\cdots$ & 2.7 & ----- & .002 & 8.1 & ----- & ---- \\
\hline \multicolumn{20}{|c|}{ Yucca Flat-- $\mathrm{NaHCO}_{3}$ ground water at depth $670-1,539 \mathrm{ft}(204-470 \mathrm{~m})$} \\
\hline \multirow[t]{2}{*}{ Y 40} & 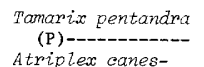 & 406532 & 14.1 & --- & 0.003 & ----- & $>10$ & ---- & 17.6 & --- & 4.0 & --- & 8.2 & ---- & 0.07 & ------ & --- & 1.7 & --- \\
\hline & $\begin{array}{l}\text { Atriplex canes- } \\
\text { oens (P)--- } \\
\text { North playa soil } \\
\text { in catt1e }\end{array}$ & 411573 & 23.0 & --- & .002 & ----- & .5 & ---- & 6.6 & ---- & 3.6 & ---- & 32.0 & --- & .01 & $-\cdots-$ & ---- & ----- & --- \\
\hline Y5 & $\begin{array}{l}\text { reservoir----- } \\
\text { South playa clay }\end{array}$ & 411564 & $\cdots$ & -- & ---- & 0.004 & ----- & 1.0 & ----- & 2.0 & ----- & 1.2 & ----- & 3.0 & ----- & 0.007 & 1.4 & ----- & --- \\
\hline & $\begin{array}{l}\text { at crack } 0-1.5 \\
\text { (no vegetation) }\end{array}$ & 403218 & ---- & -- & ---- & .007 & ----- & 1.9 & $\cdots$ & 3.7 & -..- & .74 & $\cdots$ & 3.1 & .... & .005 & 3.1 & & \\
\hline & at $1.5-15 \mathrm{~cm}--$ & 403219 & $\cdots$ & --- & ----- & .005 & ----- & 1.9 & ---- & 3.8 & ----- & .74 & ----- & 3.0 & ----- & .003 & 2.9 & $\begin{array}{l}<.01 \\
-\cdots--\end{array}$ & $<0.01$ \\
\hline & 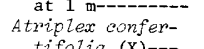 & 403220 & ---- & 0.10 & ---- & $\mathrm{N}$ & ----- & 1.2 & $\cdots$ & 1.3 & $-\cdots$ & 1.3 & $\cdots$ & 3.3 & $\cdots$ & .003 & .15 & --- & $<.01$ \\
\hline Y14 & $\begin{array}{l}\text { tifolia }(\mathrm{X})--- \\
\text { Sandy alluvium-- } \\
\text { Lucium andersoni }\end{array}$ & $\begin{array}{l}403522 \\
403221\end{array}$ & $\begin{array}{l}17.3 \\
---\end{array}$ &.-15 & $\begin{array}{c}.003 \\
-.--\end{array}$ & .005 & $\begin{array}{r}2.0 \\
---.\end{array}$ & 1.2 & $\begin{array}{c}1.3 .1 \\
----\end{array}$ & 2.8 & $\begin{array}{l}10.6 \\
----\end{array}$ & 1.5 & 14.4 & 3.2 & $\begin{array}{c}.007 \\
---\end{array}$ & .003 & 1.1 & $\begin{array}{r}.55 \\
-.5 \\
-\end{array}$ & .02 \\
\hline 114 & (X) & 408648 & 8.5 & --- & .03 & ----- & 2.0 & --- & 25.2 & ---- & .20 & --- & 15.2 & ---- & .02 & ----- & -...- & .52 & ---- \\
\hline & $\begin{array}{l}\text { Salsola kazi (X) } \\
\text { Alluvium----- }\end{array}$ & $\begin{array}{l}408649 \\
118531\end{array}$ & 22.8 & .08 & N & .0035 & $\begin{array}{r}1.5 \\
----\end{array}$ & .54 & $\begin{array}{r}8.6 \\
---\end{array}$ & 1.3 & .35 & $\overline{1.6}$ & 27.2 & 3.0 & .01 & $\begin{array}{r}.003 \\
-----\end{array}$ &..-15 & $\begin{array}{r}.34 \\
---\end{array}$ & -01 \\
\hline & & & & & Kawic & ich valle & ey-- NaHCC & $\mathrm{CO}_{3}$ grou & ind water & er at de & epth 660 & $\mathrm{ft}(20$ & $0 \mathrm{~m})$ & & & & & & \\
\hline K12 & $\begin{array}{l}\text { Atriplex confer- } \\
\text { tifolia }(\mathrm{x})--\end{array}$ & 3585 & 11.7 & ---- & 0.0045 & & 2.0 & ---- & 11.2 & --- & 11.8 & --- & 13.2 & $-\ldots$ & 0.01 & & $\ldots+-$ & 0.36 & \\
\hline K44 & $\begin{array}{l}\text { Playa clay---- } \\
\text { Playa clay (no }\end{array}$ & 403255 & --- & 0.05 & - & 0.005 & ---- & 1.3 & $\cdots$ & 1.8 & --- & 1.5 & $\cdots .$. & 3.3 & $\cdots$ & 0.005 & 0.55 &.- .50 & 0.17 \\
\hline & vegetation)--- & 405840 & --- & .76 & ------ & .008 & ---- & 1.8 & ----- & 3.2 & ----- & .89 & ---- & 3.2 & --- & .005 & 2.2 & --- & 1.3 \\
\hline & & & & & & Gold & d Flat--1 & $\mathrm{NaHCO}_{3}$ & ground w & water a & at depth & $230 \mathrm{ft}$ & $(70 \mathrm{~m})$ & & & & & & \\
\hline GF33 & $\begin{array}{l}\text { Kochia americana } \\
\text { (P)- }\end{array}$ & 405816 & 24.8 & --- & 0.002 & ---- & 2 & --- & 8.8 & --- & 24 & --- & 15 & ---- & 0.02 & $-\cdots$ & --- & 0.49 & --- \\
\hline & $\begin{array}{l}\text { Suredada ociden- } \\
\text { talis (P)-- } \\
\text { Silty }\end{array}$ & 405817 & 29.0 & --- & .015 & ----- & 1.5 & ---- & 3.8 & ---- & 31 & --- & 9.4 & ---- & .015 & --.-- & --- & .68 & --- \\
\hline & $\begin{array}{l}\text { Silty sulfate } \\
\text { zone------- }\end{array}$ & 405844 & --- & 2.1 & ----- & 0.008 & ----- & 1.5 & ----- & 4.5 & ----- & 1.3 & ---- & 3.2 & ----- & 0.005 & 1.6 & ---- & 5.4 \\
\hline & & & & & Cactus & is Flat-- & $-\mathrm{NaHCO}_{3} \&$ & ground & water at & at depth & 2. $110-443$ & $3 \mathrm{ft}(3$ & 35-135 m & & & & & & \\
\hline c3 & $\begin{array}{l}\text { Atriplex confer- } \\
\text { tifolia (X)--- } \\
\text { Eurotia lanata }\end{array}$ & 405822 & 10.5 & --- & 0.0035 & ---- & 2.0 & $-\cdots$ & 7.0 & --- & 17 & ---- & 14 & ---- & 0.01 & ----- & $-\cdots$ & --- & ---- \\
\hline & $\begin{array}{l}\text { (X) - } \\
\text { Alluvium-- }\end{array}$ & $\begin{array}{l}405823 \\
405845\end{array}$ & $\stackrel{11.0}{---}$ & 0.004 & \begin{tabular}{c}
.015 \\
- \hdashline-
\end{tabular} & 0.004 & $\begin{array}{r}2.0 \\
----\end{array}$ & 1.0 & $\begin{array}{r}7.0 \\
-\end{array}$ & $-\overline{2.0}$ & $\begin{array}{c}1.1 \\
-\cdots\end{array}$ & ---- & 16 & ---- & $\begin{array}{r}.02 \\
-.-\end{array}$ & $<0.002$ & --- & --- & ---- \\
\hline & & & & & onewa11 F & lat--alt & tered $\mathrm{NaF}$ & $\mathrm{HCO}_{3} \mathrm{gr}$ & round wat & iter at & depth 10 & $.00-275$ & ft $(30-\varepsilon)$ & $85 \mathrm{~m})$ & & & & & \\
\hline C5 & $\begin{array}{l}\text { Atrintex confer- } \\
\text { tijolia }(\mathrm{X})-- \\
\text { Lepidium }\end{array}$ & 405826 & 17.5 & ---- & 0.05 & --- & 1.5 & $\cdots$ & 5.0 & $\cdots$ & 20 & ---- & 9.4 & ---- & 0.02 & ------ & --- & --- & $\cdots$ \\
\hline & $\begin{array}{c}\text { fremonti }(\mathrm{t})-- \\
\text { Alluvium--- }\end{array}$ & $\begin{array}{l}405827 \\
405847\end{array}$ & $\begin{array}{r}5.3 \\
---\end{array}$ & 0.1 & $\begin{array}{r}.004 \\
---\end{array}$ & 0.007 & $\begin{array}{r}2.0 \\
----\end{array}$ & $\overline{1.0}$ & Ma & $-\overline{3.0}$ & $\begin{array}{c}2.4 \\
----\end{array}$ & 3.0 & 21 & --- & $\begin{array}{r}.03 \\
-0-\end{array}$ & 0.003 & ---- & --- & --- \\
\hline & & & & & & y Lake v & 11 ey--8 & ground & later at & it depth & $>300 \mathrm{ft}$ & ft $\quad(>90$ & & & & & & & \\
\hline L22 & $\begin{array}{l}\text { Atriplex linernis } \\
\text { (P)-atifomis }\end{array}$ & 413074 & 15 & ----- & 0.002 & $-\cdots$ & 7.0 & --- & 15 & --- & 0.26 & --- & 21 & ---- & 0.02 & --.-- & --- & 0.65 & --- \\
\hline & $\begin{array}{l}\text { (P)-- } \\
\text { Playa sands------ }\end{array}$ & $\begin{array}{l}413075 \\
413112\end{array}$ & $\begin{array}{l}19 \\
---\end{array}$ & ---- & $\begin{array}{r}.013 \\
---\end{array}$ & 0.005 & $\begin{array}{r}10.0 \\
---\end{array}$ & 2.0 & $\begin{array}{r}9.2 \\
---\end{array}$ & $---\overline{9}$ & 12 & 0.70 & 17 & 2.0 & $\begin{array}{c}.02 \\
----\end{array}$ & 0.007 & ---- & $\begin{array}{r}.77 \\
---\end{array}$ & 0.15 \\
\hline & & & & & & & & & 11ver Lak & & & & & & & & & & \\
\hline L21 & $\begin{array}{l}\text { Atriplex poly- } \\
\text { carpa (P)--- } \\
\text { Sandy soil at }\end{array}$ & 413090 & 13 & ---- & 0.002 & ----- & 7.0 & ---- & 6.0 & ---- & 16 & $-\cdots$ & 16 & --- & 0.05 & ------ & ---- & 0.46 & ---- \\
\hline & $\begin{array}{l}\text { playa edge---- } \\
\text { Playa mud (no }\end{array}$ & 413124 & $-\cdots$ & ----- & ---- & 0.007 & ----- & 2.0 & $\cdots$ & 3.4 & $\cdots$ & 2.2 & ---- & 2.3 & --- & 0.002 & --- & --- & 0.02 \\
\hline & vegetation)---- & 415475 & --- & 2.0 & ---- & .008 & ----- & 2.0 & ----- & 3.8 & ---- & 2.5 & --- & 1.9 & ---- & .007 & ---- & ---- & .54 \\
\hline
\end{tabular}

${ }^{1}$ Fluorine content of plant: 0.0063 percent. 
TABLE 7.-Percentage of lithium and associated ions in basin sediments, collected within 6 inches (15 cm) of the ground surface [N, not detected; number of samples shown in parentheses]

\begin{tabular}{|c|c|c|c|c|c|c|c|c|c|c|}
\hline & \multicolumn{3}{|c|}{ Li thium } & \multicolumn{2}{|c|}{ Magnesium } & \multirow{2}{*}{$\frac{\mathrm{Mg} / \mathrm{Li}}{\text { Ratio }}$} & \multicolumn{2}{|c|}{ Potassium } & \multicolumn{2}{|c|}{ Boron } \\
\hline & Median & & ange & Median & Range & & Median & Range & Median & Range \\
\hline \multicolumn{11}{|c|}{ Closed basins } \\
\hline Lake clay (5) associated with volcanics-- & 0.07 & 0.03 & -0.2 & 3.0 & $0.3-11.0$ & 43. & 1.7 & $0.24-2.4$ & 0.005 & $0.002-0.015$ \\
\hline Spring-deposited tufa and lake marls (8)- & .045 & .003 & -.20 & 2.85 & $.33-5.0$ & 63. & .73 & $.1-18.0$ & .003 & $<.002-.03$ \\
\hline Ch1oride zone (13)---1-- & .015 & .0025 & $5-.03$ & 2.0 & $.03-4.0$ & 133. & 1.9 & $.8-2.4$ & .03 & $.015-.07$ \\
\hline Sulfate-chloride mixed (9)-- & .015 & .003 & -.03 & 1.7 & $.07-5.0$ & 113. & 2.9 & $.24-3.7$ & .05 & $\mathrm{~N}-.15$ \\
\hline Black oozes in hot springs (6)-- & .01 & .004 & -.08 & 1.0 & $.70-2.0$ & 100 & 1.12 & $.34-3.0$ & .005 & $.002-.02$ \\
\hline Carbonate zone (11)------ & .015 & $\mathrm{~N}$ & -.03 & 1.0 & $.07-4.8$ & 66. & 2.3 & $.24-3.6$ & .015 & $\mathrm{~N}-.03$ \\
\hline Playa clays, calcareous (7)-- & .015 & .006 & -.023 & 1.3 & $.7-3.2$ & 86. & 2.45 & $2.3-2.6$ & .019 & $.005-.07$ \\
\hline Alluvium (4)- & .003 & $\mathrm{~N}$ & -.005 & 1.0 & $1.0-1.1$ & 333. & 3.0 & $2.8-3.5$ & .003 & $<.002-.005$ \\
\hline Basin sands (6)- & .004 & $\mathrm{~N}$ & -.017 & 1.5 & $.48-3.0$ & 375. & 2.4 & $2.0-3.4$ & .005 & $.003-.2$ \\
\hline \multicolumn{11}{|c|}{ Open basins } \\
\hline Sulfate zone (1)- & 0.008 & $-\cdots$ & ----- & 1.5 & ------- & 187. & 3.2 & ----- & 0.005 & ------ \\
\hline Playa clays (12)-- & .005 & $\mathrm{~N}$ & -0.015 & 2.0 & $1.0-3.2$ & 400 & 2.7 & $1.9-3.3$ & .005 & $\odot 0.002-0.007$ \\
\hline Playa sands (2)--- & .006 & 0.005 & -.007 & 2.0 & -------- & 333. & 2.2 & $2.0-2.3$ & .004 & $.002-.007$ \\
\hline Alluvi um (4)-- & .005 & .004 & -.007 & 1.0 & $.54-1.2$ & 200 & 3.1 & $3.0-5.0$ & .003 & $<.002-.003$ \\
\hline
\end{tabular}

\section{HYDROLOGICALLY CLOSED BASINS}

Lithium is concentrated particularly in the evaporites, spring deposits, and lacustrine clays of closed basins. The maximum lithium concentration found in sediment and clay samples that were collected in 12 closed basins in Nevada and California ranged from 30 to $2,000 \mathrm{ppm}$. Samples collected from lacustrine clay deposits have a median concentration of $700 \mathrm{ppm}$ lithium; springdeposited tufa and lake marls, $450 \mathrm{ppm}$; those from the sulfate, chloride, and carbonate zones and, also, those from playa clays, which commonly contain considerable detrital calcium carbonate, contain $150 \mathrm{ppm}$; samples of organic black oozes in hot springs, $100 \mathrm{ppm}$; alluvium and basin sands from the fans that surround the basins, 30 and $40 \mathrm{ppm}$ (table 7). Apparently lithium and boron differ in their geochemical behavior. Lithium becomes concentrated in lake clays, particularly those of volcanic origin and in spring deposits, whereas boron does not. A general increase for both lithium and boron content from the fans to the center of the basin is probably real, as shown by samples collected in Death Valley (fig. 1), although the content of a particular zone is not consistently high or consistently low.

A close correlation of lithium, boron, and potassium might be expected in view of their common volcanic origin and their precipitation at a late stage in brine evaporation. There is little zonal variation in the potassium concentrations of basin sediments, although the brines are highly enriched in potassium. However, the boron contents increase from $30 \mathrm{ppm}$ in alluvium on the fans to $500 \mathrm{ppm}$ in the sulfate-chloride zone in the central parts of the basins. Neither element is precipitated in quantity in the spring deposits. In evaporites, the boron content exceeded the lithium content, but in detrital sediments the reverse was found.

The magnesium content of the basin sediments varies widely because it occurs in residual dolomite that has been deposited in the carbonate zone and in the playas. Magnesium also occurs in sulfates and chlorides that have been precipitated from evaporite brines. The magnesium:lithium ratio varies from basin to basin, which affects the economic value of the deposits, a low magnesium:lithium ratio being most desirable. The ratio is lowest in collections from Owens Valley and is also relatively low in spring deposits and lake clays.

The amount of lithium found in the spring-deposited tufas and the marls of springs that occur at the alluviumevaporite contact in these closed basins is much greater than the average content of lithium in marine limestones. The phenomenon probably reflects a secondary cycling in the basins, as lithium trapped in clays and other sediments may be easily returned to solution by thermal waters. Hot springs are highly charged with carbon dioxide, and so alkali carbonates precipitate around the orifice of a spring of low discharge due to evapotranspiration, respiration, and decay of marsh vegetation (Jones, 


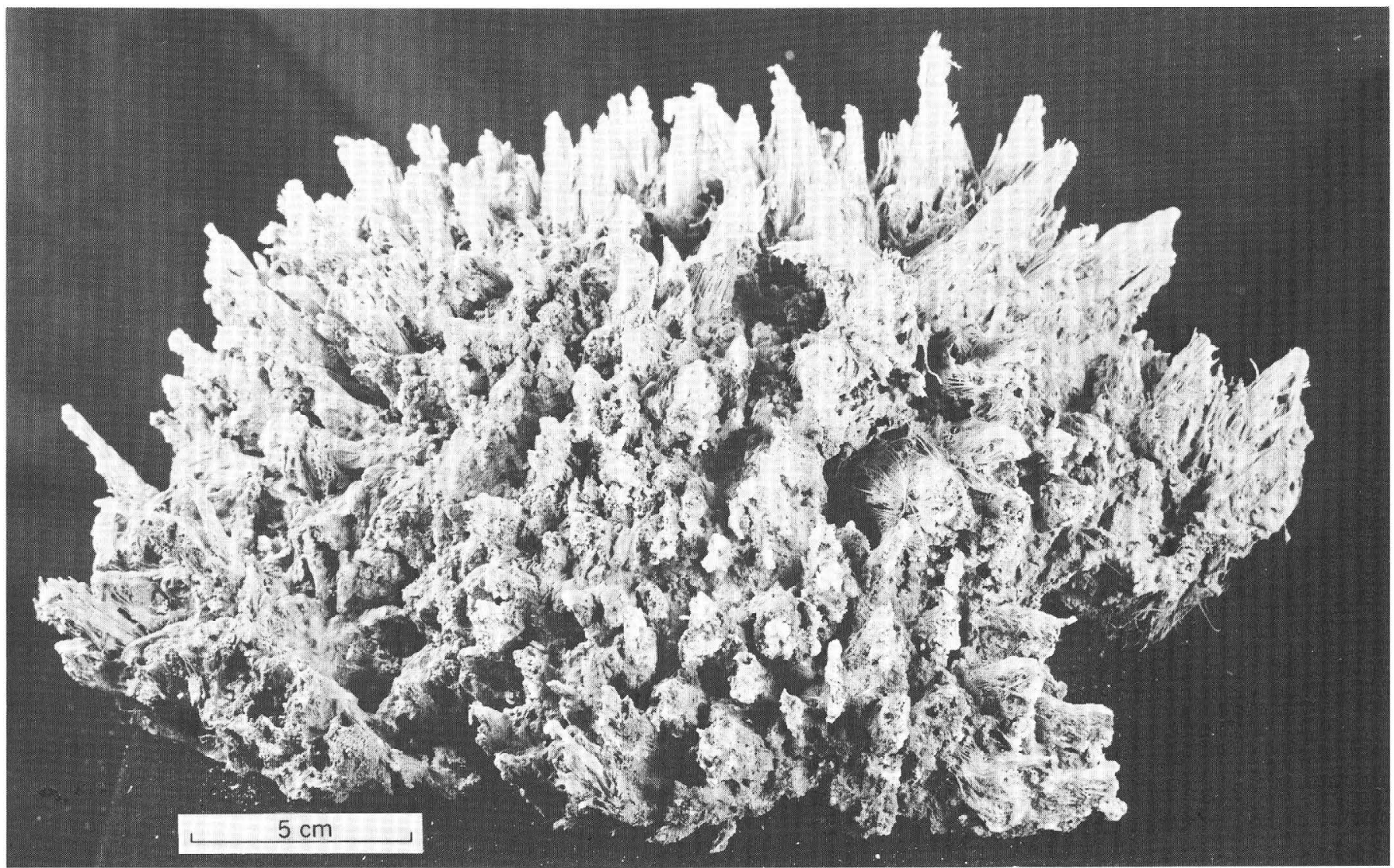

FIGURE 3.-Crown of rush killed by hot-spring precipitate, Clayton Valley, Sample from station L4B.

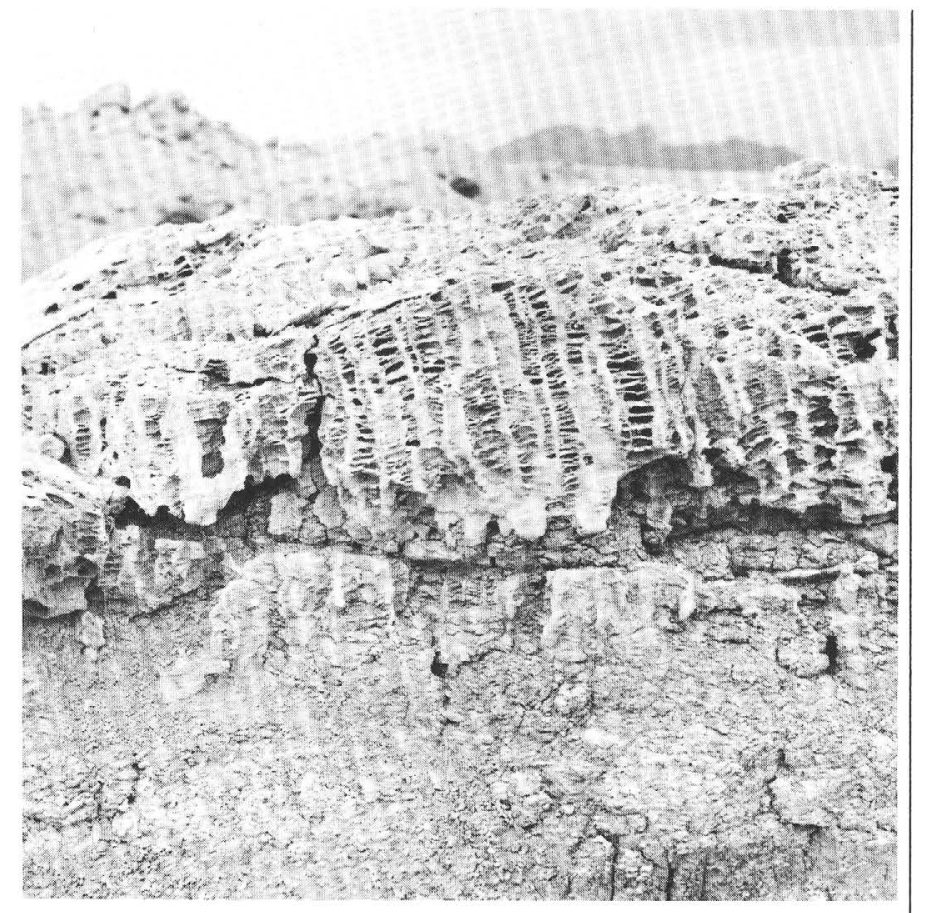

FIGURE 4.-Precipitate of biogenous origin occurring in place, Amargosa Desert. Sample from Station A5B.
1966). Such concentrations around the roots of rushes (Juncus cooperi) in a hot spring of Clayton Valley gradually kills the plants. These "fossilized" root crowns contain more than 1,000 ppm lithium (fig. 3). Lithium-rich lacustrine deposits of marl and clay commonly show a definite root-cast structure that suggests precipitation around plant debris and in old root casts in marls of Amargosa Desert (figs. 4, 5, 6).

Thus, the lithium content of many types of sediment is highest in closed basins discharged by evapotranspiration, particularly basins that receive recharge from several adjacent basins. Within a given basin, lithium is particularly concentrated in lacustrine deposits of volcanic.origin and in biogenous deposits precipitated from thermal waters associated with these closed basins.

\section{DEATH VALLEY}

Death Valley is a closed basin from which no water escapes, as the floor of the valley extends 280 feet below sea level. Old shorelines mark the lowering by evaporation of Pleistocene Lake Manley, which was originally 600 feet $(180 \mathrm{~m})$ deep. Mineralized water has also been contributed yearly by freshwater rivers and by underflow from nearby 


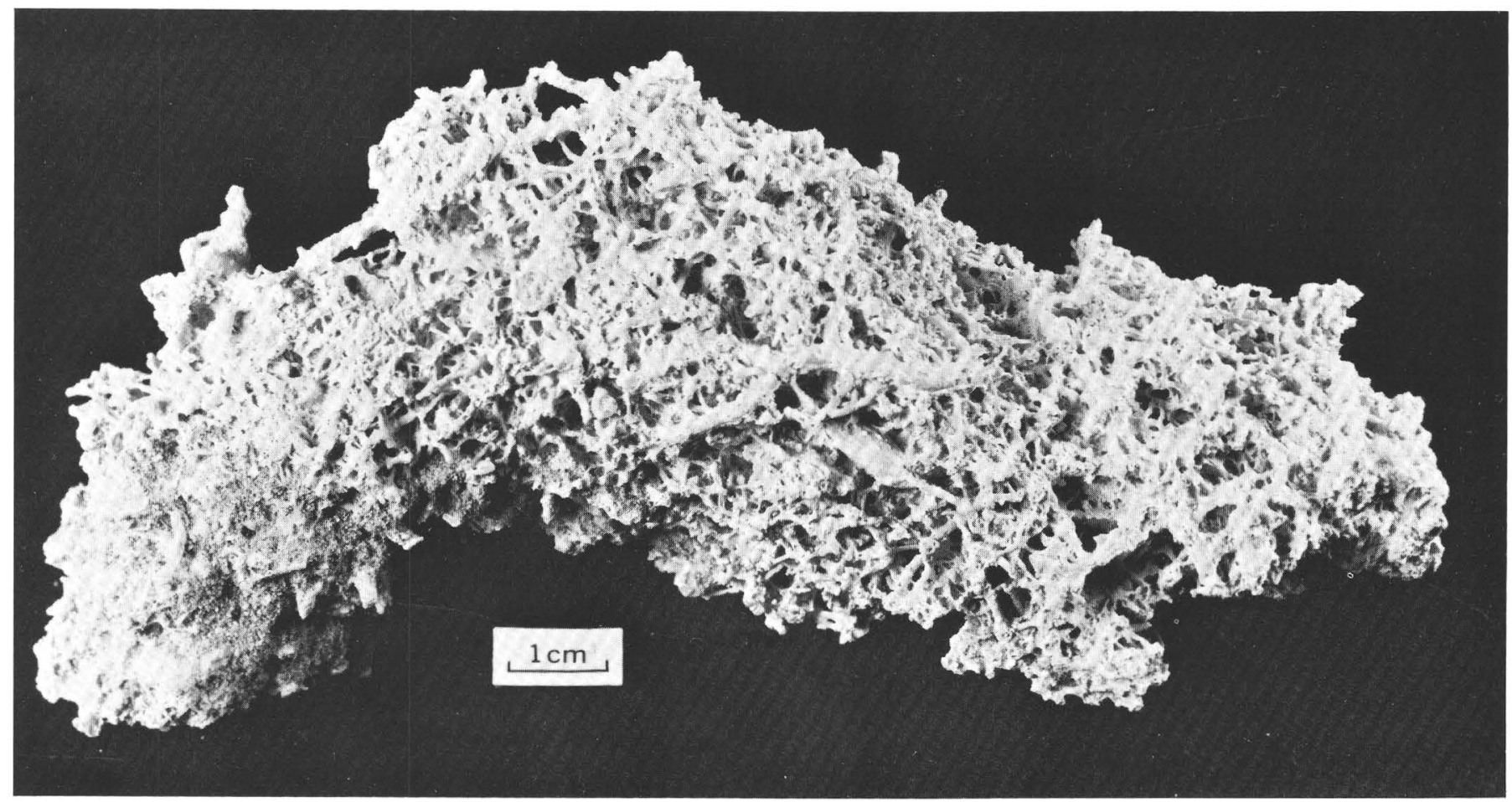

FIGURE 5.-Calcium carbonate precipitate on organic detritus, Amargosa Desert. Sample from station A5.

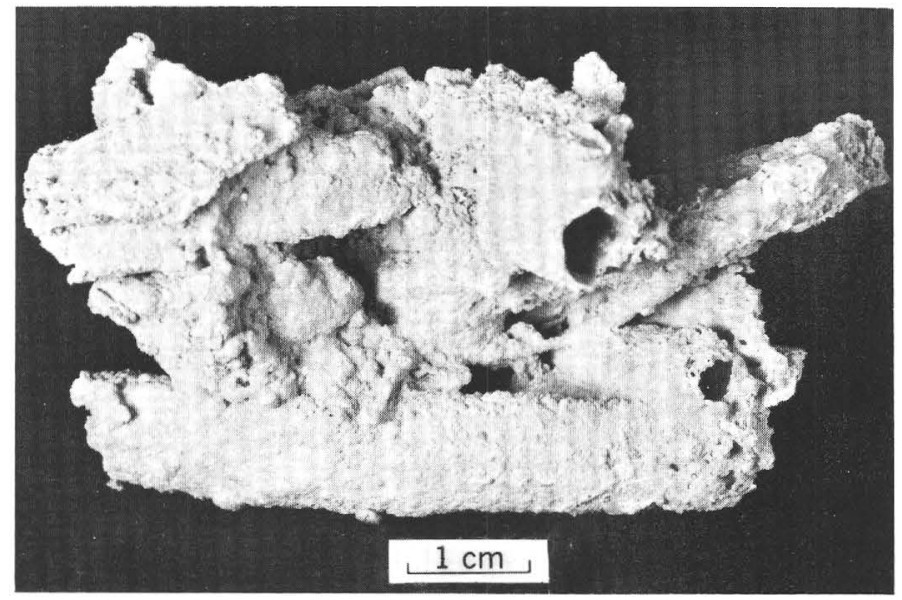

Figure 6.-Cast of former root or stem structure, Amargosa Desert. Sample from station A5A.

basins (Hunt and Robinson, 1960). Thus, lithium has been concentrated as a residue in the mother liquor in this evaporite basin from an enormous quantity of water and has been redistributed laterally through seasonal flooding and hot-spring action.

Discharge by evapotranspiration of this large quantity of water has resulted in a lateral zonation of salts characterized by chlorides in the center of the basins ringed successively by sulfates and carbonates. The carbonate and sulfate zones are commonly contaminated with salt (sodium chloride) during seasonal flooding. Groundwater conditions are rarely homogeneous to the depth penetrated by plant roots because permeable layers alternate with impermeable layers. The carbonate zone may be underlain by a caliche of sulfates, and so forth (Hunt and others, 1966).

Only bacteria grow in the chloride zone of the salt pan and fungi and algae in the sulfate zone (Hunt, 1966). Pickleweed (Allenrolfea) grows on the sand facies of the carbonate zone where the sands are impregnated with salt. Sixty percent of the ash of this plant is composed of sodium chloride, and mounds of exudated salt build up as high as 2 feet $(0.6 \mathrm{~m})$ around the base of the plant (fig. 7$)$. Saltgrass (Distichlis), which grows on the same sand facies, contains a lesser percentage of salt in the ash, but the true amount of salt in the plant is masked by the large amount of silica in the ash which affects all the percentage values. Arrowweed (Pluchea) absorbs large amounts of sulfate but little sodium chloride. Arrowweed is restricted to soils of less than 5 percent water-soluble salts and mesquite to less than 0.5 percent. Thus, mesquite (Prosopis) grows only around springs of relatively fresh water that issue along the contact between the alluvial fans and the salt pan. Xerophytes, such as desertholly (Atriplex hymenelytra), cattle spinach ( $A$. polycarpa), and creosotebush (Larrea) cover the alluvial fans (Hunt, 1966).

Hunt (1966) reported the following percentage con- 


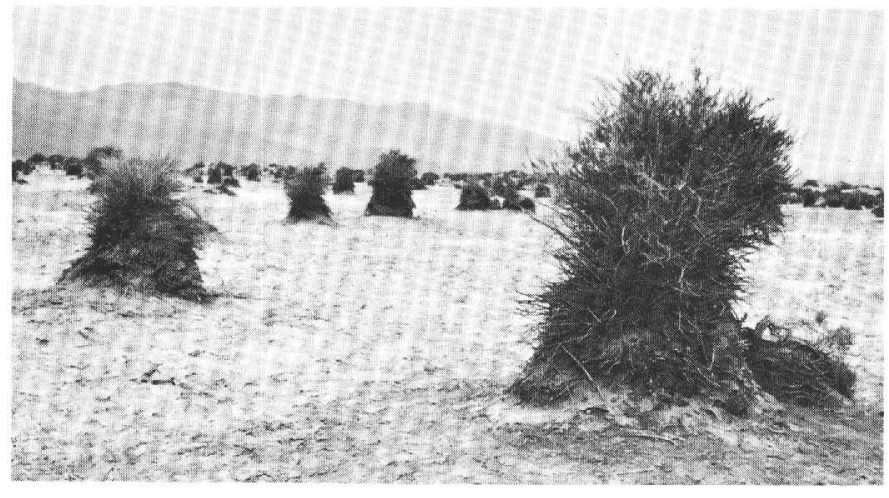

FIGURE 7.-Pickleweed (Allenrolfea) on salt mounds in Death Valley. Mound beneath near bush is approximately 2 feet $(0.6 \mathrm{~m})$ high.

centration of major ions in the ash of some Death Valley plants:

\begin{tabular}{|c|c|c|c|c|c|c|c|c|}
\hline $\begin{array}{c}\text { Plant name and number } \\
\text { of samples }\end{array}$ & $\mathrm{Ca}$ & $\mathrm{Mg}$ & $\mathbf{K}$ & $\mathrm{Na}$ & $\mathrm{SO}_{4}$ & $\mathrm{Cl}$ & $\begin{array}{c}\mathrm{CO}_{3} \text { or } \mathrm{PO}_{4} \\
\text { needed to } \\
\text { balance } \\
\text { cations }\end{array}$ & $\mathrm{SiO}_{2}$ \\
\hline \multicolumn{9}{|c|}{ Xerophytes } \\
\hline Atriplex hymenelytra (2)..... & 6 & 2 & 7 & 26 & 4 & 25 & 30 & $\ldots$ \\
\hline Atriplex polycarpa (1)......... & 11 & 6 & 8 & 14 & 4 & 14 & 40 & $<5$ \\
\hline \multicolumn{9}{|c|}{ Phreatophytes } \\
\hline Pluchea (6).................... & 11 & 4 & 10 & 12 & 23 & 8 & 32 & \\
\hline 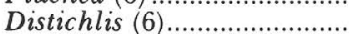 & 2 & 1 & 2 & 6 & 5 & 9 & 5 & $\dddot{70}$ \\
\hline 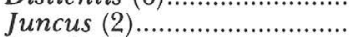 & 4 & 2 & 19 & 8 & 13 & 9 & 20 & 25 \\
\hline 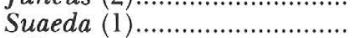 & 3 & 5 & 9 & 20 & 8 & 20 & 35 & $\ldots$ \\
\hline 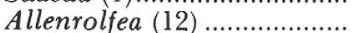 & 2 & 2 & 5 & 32 & 7 & 27 & 25 & $\begin{array}{l}\cdots \\
\ldots\end{array}$ \\
\hline Atriplex linearis (1)............. & $\overline{9}$ & 4 & 13 & 17 & 5 & 12 & $\ldots$ & \\
\hline
\end{tabular}

The relatively constant ratio of sodium to chloride in the plants suggests that the two ions are absorbed together. The correlation between lithium and sodium shown in our analyses suggests that lithium is adsorbed as a chloride.

Our samples in Death Valley came chiefly from the carbonate zone, the lower parts of the alluvial fans, and near springs so that we could study the uptake of ions by plants (table 8). The content of water-soluble salts in the soils that were collected at plant sample localities was higher in several instances than the tolerance limits reported for these species because the samples were of surface soils and included an efflorescent crust. The soils actually in contact with the plant roots (for example, mesquite) may be as much as 50 feet $(15 \mathrm{~m})$ below the surface.

In general, lithium contents in surface sediments of this evaporite basin decrease laterally from the center outward:

Chloride and sulfate zones.....150-300 ppm

Carbonate zone.........................30-150 ppm

Alluvium and dune sand..... $35-50 \mathrm{ppm}$

Anomalous amounts of lithium (300 ppm) were detected in the travertine deposits of Travertine Spring in Furnace Creek Wash, the sulfate sediments at Badwater, and in the sediment (as opposed to the halite pinnacles) of the salt pan or chloride zone (D1A). This concentration was found in the brown soft sediment below the polygonal hard crust of the streambed which meanders across the salt pan. The surface polygons of halite with upturned edges are hard enough to support a man's weight.

Lithium in the ash of plants that were collected in Death Valley ranges from 30 to $500 \mathrm{ppm}$ in the ash, or 7.3 to 160 ppm dry weight. Plants containing high lithium correspond with high lithium in the substrate. The highest concentrations of lithium are in Allenrolfea (pickleweed), in Atriplex hymenelytra (desertholly) and Suaeda ramossissima (seepweed) collected near the edge of the salt zone where the roots presumably are periodically contaminated with salt during floods. The blue-green algae at Badwater (sta. D8) in the sulfate zone (which is also high in sodium chloride) contained only $110 \mathrm{ppm}$ lithium, a surprising low value considering the metal-accumulative ability of most algae.

\section{AMARGOSA DESERT}

The Amargosa Desert is not topographically closed; the Amargosa River flows into it from Oasis Valley in the northwest corner and out into Death Valley at the southeast corner. Nevertheless, little water is actually lost from the valley because the streambed is completely dry in the summer, when the temperatures and evaporation rates are high. Hydrologically, therefore, the basin is presumed to be closed and is characterized by a noticeable upwelling of ground water in many large springs; even that flow is consumed in the summer by evapotranspiration. The chemistry of Death Valley waters shows (Hunt and Robinson, 1960) that a certain amount of water from the Amargosa Desert is discharging by underflow into Death Valley. According to Winograd (1962), who studied the altitude of the piezometric surface of the semiperched Cenozoic aquifers in Yucca, Frenchman, and Jackass Flats, the ground water of these valleys moves downward into the underlying Paleozoic carbonates and discharges into the Amargosa Desert.

Analyses of water from springs and wells (Walker and Eakin, 1963; B. P. Robinson and W. A. Beetam, written commun., 1965) show high calcium and magnesium in the ground water discharged largely from limestones in the northeastern part of the valley and high bicarbonate, sulfate, chloride, sodium, fluorine, potassium, and boron in waters recharged largely from tuffs in the western part of the valley (table 9). Water from Jackass Flats, which is unusually high in sulfate attributed by Schoff and Moore (1964) to hydrothermal alteration of volcanic rocks, contributes sulfate and probably lithium to the western part of Amargosa Desert. Water from a shallow well southeast of Allens Well and 2 miles $(1.2 \mathrm{~km})$ south of station A4 contains $0.30 \mathrm{ppm}$ lithium and $2.8 \mathrm{ppm}$ boron-the highest percentages recorded by Walker and Eakin for their 18 Amargosa water samples. According to Walker and Eakin, the boron content should be toxic to any but the most 
TABLE 8.-Percentage of lithium and associated ions in sediments and the ash of plants from Death Valley, Calif.

[Stations shown in fig. I. Analysts are named in introduction. N. not detected; X, xerophyte; P, phreatophyte; Ha, halophyte; Hy, hydrophyte; WSS, water-soluble salts. The soil in which the sampled plant grew is listed directly below each plant]

\begin{tabular}{|c|c|c|c|c|c|c|c|c|c|c|c|c|c|c|c|c|c|c|c|c|}
\hline \multirow[t]{2}{*}{$\begin{array}{l}\text { Sta- } \\
\text { tion } \\
\text { No. }\end{array}$} & \multirow[t]{2}{*}{ Sample } & \multirow[t]{2}{*}{$\begin{array}{l}\text { Lab. } \\
\text { No. } \\
\text { (D-) }\end{array}$} & \multirow{2}{*}{\multicolumn{2}{|c|}{$\begin{array}{l}\text { Ash WSS } \\
\text { (percent) }\end{array}$}} & \multicolumn{2}{|c|}{ Lithium } & \multicolumn{2}{|c|}{ Magnesium } & \multicolumn{2}{|c|}{ Calcium } & \multicolumn{2}{|c|}{ Sodium } & \multicolumn{2}{|c|}{ Potassium } & \multicolumn{2}{|c|}{ Boron } & \multirow{2}{*}{$\begin{array}{c}\begin{array}{c}\text { Carbo- } \\
\text { nate } \\
\text { (as } \\
\left.\mathrm{CO}_{2}\right)\end{array} \\
\text { Soil }\end{array}$} & \multicolumn{2}{|c|}{$\begin{array}{l}\text { Sulfate } \\
\text { (water- } \\
\text { soluble) }\end{array}$} & \multirow{2}{*}{$\begin{array}{l}\text { Chlorine } \\
\frac{\text { Soi1 }}{}\end{array}$} \\
\hline & & & & & Plant & Soil & Plant & Soil & Plant & Soil & Plant & Soil & Plant & Soil & Plant & Soil & & Plant & Soil & \\
\hline \multicolumn{21}{|c|}{ At edge of salt pan, west of Devil's Golf Course } \\
\hline \multirow[t]{6}{*}{ D1A } & $\begin{array}{l}\text { Allenrolfea occi- } \\
\text { dentalis (Ha)--- } \\
\text { Sediment mixed }\end{array}$ & 403640 & 27.5 & --- & 0.035 & ---- & 2.0 & --- & 2.7 & --- & 33.2 & --- & 6.4 & --- & 0.05 & --- & --- & 0.50 & --- & --- \\
\hline & with halite----- & 403338 & --- & 2.8 & ---- & 0.015 & --- & 4.0 & --- & 7.8 & ---- & 8.3 & ---- & 1.7 & ---- & 0.03 & 6.2 & ---- & 1.72 & 28.5 \\
\hline & $\begin{array}{l}\text { Salt pinnacle } \\
\text { (no plants)----- }\end{array}$ & 405463 & --- & -- & ---- & .02 & -n- & .07 & --- & .50 & ---- & 35 & ----- & .8 & ----- & .07 & --- & --- & 2.0 & --- \\
\hline & Brown sediment be- & & & & & & & & & & & & & & & & & & & \\
\hline & $\begin{array}{l}\text { tween pinnacles- } \\
\text { Streambed to salt }\end{array}$ & 405464 & --- & --- & ----- & .03 & --- & 1.0 & --- & 3.0 & ---- & 20 & ----- & 1.7 & ---- & .15 & ---- & --- & 4.5 & --- \\
\hline & $\begin{array}{c}\text { zone--------- } \\
\text { Atriplex hymene- }\end{array}$ & 405465 & --- & --- & ---- & .03 & --- & 2.0 & --- & 5.1 & ----- & 15 & --- & 1.9 & ---- & .10 & --- & --- & 9.4 & $\cdots$ \\
\hline \multirow{3}{*}{ D1B } & $\begin{array}{l}\text { lytra }(\mathrm{X})- \\
\text { Suaeda ramossis- }\end{array}$ & 403642 & 32.3 & --- & .03 & ---- & 1.5 & --- & 5.4 & --- & 31.3 & --- & 5.4 & $\cdots$ & .02 & --- & -- & .71 & --- & --- \\
\hline & $\begin{array}{l}\text { sima }(\mathrm{P}) \text {--------- } \\
\text { Carbonate zone }\end{array}$ & 403641 & 22.5 & --- & .05 & ---- & 1.5 & --- & 3.2 & ---- & 31.5 & --- & 6.4 & --- & .02 & --- & --- & 1.2 & ---- & --- \\
\hline & $\begin{array}{l}\text { plus salt------- } \\
\text { Atriplex hymene- }\end{array}$ & 403339 & --- & .85 & ---- & .007 & ----- & 3.2 & --- & 8.8 & --- & 3.1 & ----- & 1.9 & $-\cdots$ & .01 & 12.2 & --- & .44 & --- \\
\hline \multirow{2}{*}{ D1C } & Lytra $(x)^{1}-$ & 412065 & 30.0 & --- & .05 & ---- & 7.0 & --- & 9.6 & ---- & 23 & --- & 7.0 & --- & .03 & ---- & --- & --- & --- & --- \\
\hline & Alluvium----------- & 412058 & --- & --- & ---- & .005 & ---- & 1.0 & --- & 1.8 & ---- & 1.3 & ---- & 3.5 & ---- & .003 & --- & -- & ---- & $-\cdots$ \\
\hline
\end{tabular}

Stovepipe Wells (spring)

D5 Atriplex linearis (P)--ontis stricta (P) - - - -------

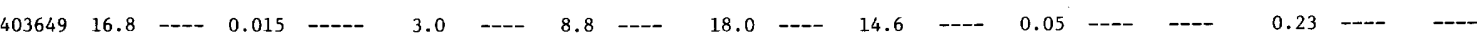
Dune

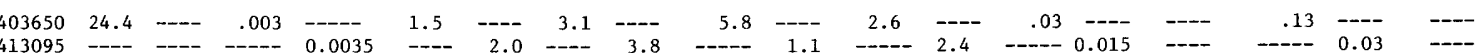

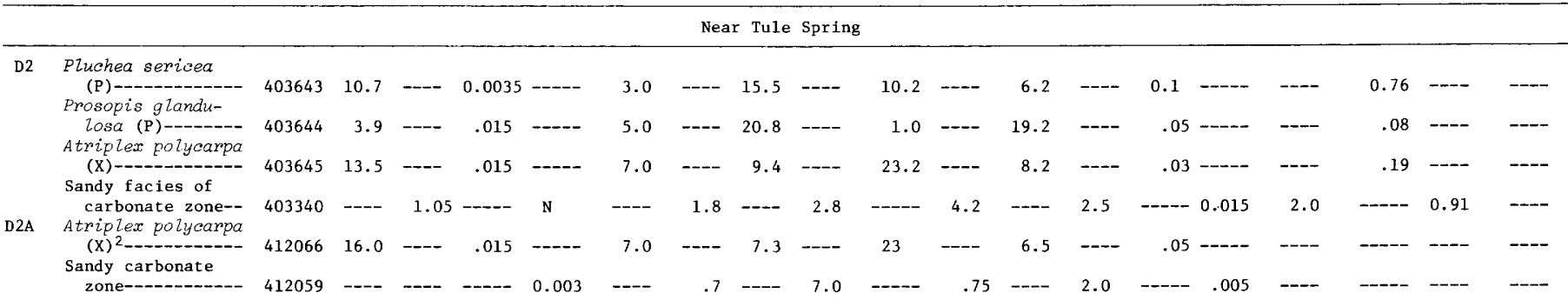
412059

D7 Allenrolfea occidentalis (Ha)--Sulfate zone plus salt----

D8 Phormidium ambiguwm----.----

Crust of gypsum---

$408644 \quad 25.5 \quad---0.03 \quad 0 .---1.5$

$30.2-\cdots \quad 8.2$

$.2 \quad--0.05----$

$4.2 \quad \cdots \quad-\cdots$

Allenrolfea ocei spongy sulfate

$118528 \quad-\ldots \quad 38.8 \quad---0.03$

$\begin{array}{lll}--- & 3.2 & ---\end{array}$

$---9.7$

$2.7 \quad---0.3$

3.2

$-5.9$

16.7

zone plus salt-- 118530 ---- $18.0 \quad-----\quad .015$

$\begin{array}{rrrrr}408645 & 87.0 & ---- & .011 & ----- \\ 118529 & --- & 5.7 & ---- & .007\end{array}$

$5.0 \quad----\quad 2.3 \quad---$

$2.0 \quad----\quad 1.4 \quad----\quad .02 \quad---$

1.0

$-22--1$

$408646 \quad 30$

$-0.03 \quad---$.

$2.0 \quad---2.0 \quad-$

$5.6 \quad--2.03---$

$--$

1.

Furnace Creek Wash, Travertine Spring

D6 Anemopsis cali-

fomica (Hy)---- $403651 \quad 16.7 \quad$---- $0.015 \quad$-----

Travertine

$5.0 \quad---\quad 5.6 \quad--$

$12.1---\quad 27.0$

$---2.6$

7.9

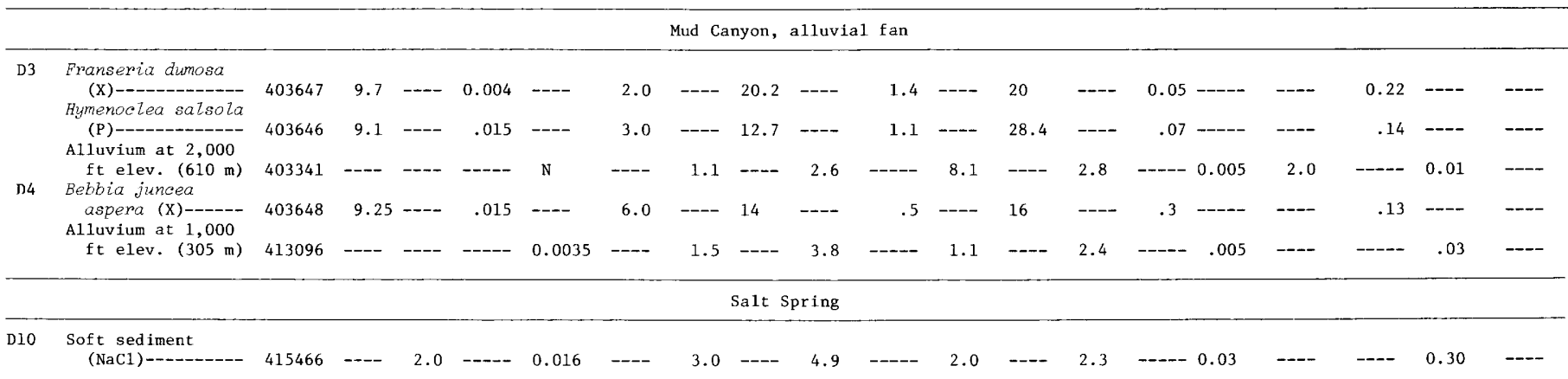

${ }^{1}$ Fluorine content in plant 0.0033 percent.

${ }^{2}$ Fluorine content in plant 0.0112 percent. 
TABLE 9.-Chemical constituents (parts per million) of some springs and wells in Amargosa Desert [Analyses from Walker and Eakin (1963, p. 33) and B. P. Robinson and W. A. Beetam (written Commún., 1965). Surface samples unless depth figure shown]

\begin{tabular}{|c|c|c|c|c|c|c|c|c|c|c|c|c|c|}
\hline $\begin{array}{c}\text { Name of spring, sample-collection } \\
\text { date, station No. }\end{array}$ & (feet) & $\underset{\text { (metres) }}{\text { Depth }}$ & $\mathrm{Ca}$ & $\mathrm{Mg}$ & $\mathrm{Na}$ & K & I & $\mathrm{HCO}_{3}$ & so & C & & & $\begin{array}{l}\text { Dissolved } \\
\text { solids }\end{array}$ \\
\hline
\end{tabular}

Recharge largely from limestones

\begin{tabular}{|c|c|c|c|c|c|c|c|c|c|c|c|c|c|c|}
\hline \multirow{3}{*}{ 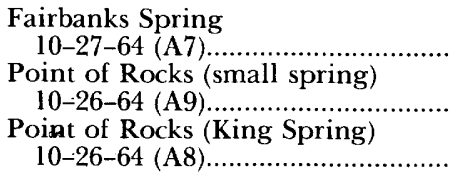 } & $\ldots$ & $\cdots$ & 51 & 18 & 71 & 8 & 0.11 & 304 & 80 & 22 & 2.2 & 0.51 & 422 & 201 \\
\hline & $\ldots$ & $\ldots$. & 52 & 19 & 66 & 7.9 & .1 & 306 & 70 & 21 & 1.2 & .66 & 419 & 208 \\
\hline & $\ldots$. & $\ldots$. & 42 & 19 & 68 & 7.9 & .09 & 308 & 70 & 22 & 1.6 & .45 & 416 & 208 \\
\hline \multicolumn{15}{|c|}{ Recharge largely from altered tuffs } \\
\hline $\begin{array}{l}\text { Southeast of Allens Well } \\
8-18-52 \text { ( } 2 \text { miles south of A4) ...... } \\
\text { Death Valley Junction }\end{array}$ & 27 & 8.2 & 4.8 & 3.3 & 370 & 16 & 0.30 & 542 & 256 & 102 & 3.2 & 2.8 & 1,119 & 26 \\
\hline 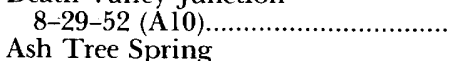 & 146 & 45 & 1.9 & 1.9 & 325 & 12 & $\ldots$. & 556 & 149 & 49 & 7.9 & 1.3 & 874 & 12 \\
\hline 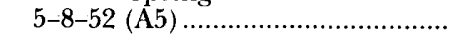 & $\ldots$. & $\ldots$. & 16 & 4.8 & 53 & 7.9 & $* .45$ & 160 & 37 & 7.2 & 2.8 & .29 & 293 & 60 \\
\hline
\end{tabular}

"USGS analysis of sample collected by H. L. Cannon.

boron-tolerant crops, and the fluorine content of $7.9 \mathrm{ppm}$ at Death Valley Junction is too high to meet U.S. Public Health Service drinking-water standards. Lithium content was not reported for Death Valley Junction but is probably also high. Two phreatophytes collected near the well contained $200 \mathrm{ppm}$ lithium and 116 and $140 \mathrm{ppm}$ fluorine in the ash.

Although correlations are apparent for lithium and sodium, lithium and chloride, and lithium and boron in the waters, no consistent relationship between lithum and any other element can be demonstrated in the various types of sediments sampled (table 10). Plant and soil studies were made in relation to a playa northeast of Ash Meadows, springs issuing from limestones in the same part of the valley, a playa northeast of Allens Well, the well at Death Valley Junction, and the clay and carbonate deposits north of Death Valley Junction. The unnamed playa is a relatively wet playa with ground water at a depth of 5-6 feet $(1.5-1.8 \mathrm{~m})$ discharging from Paleozoic limestones. Several Atriplex species were sampled in sandy soil 600 feet $(180 \mathrm{~m})$ northeast of the playa (station $\mathrm{Al})$. Also growing at the same station were the phreatophytes Prosopis (mesquite), Atriplex canescens (saltbush), and Suaeda ramossissima (seepweed) and the sulfur indicator Lepidium fremonti. No plants grew in the center of the playa, at station A2. Seepweed and shadscale were collected at station A3 where ground water stands at 6 feet $(1.8 \mathrm{~m})$ in depth in the clay pits. These clay sediments contained appreciable carbonate and sulfate and $200 \mathrm{ppm}$ lithium. At four springs issuing from Paleozoic limestones (stations A6, A7, A8, A9) only a small amount of lithium was found in tufa deposits but as much as $150 \mathrm{ppm}$ was found in organic mud in McGilivrays Spring. At the unvegetated wet playa northeast of Allens Well, the capillary fringe extends to the surface and is fed by water from the Paleozoic limestones; a maximum of $150 \mathrm{ppm}$ lithium was found in the outcropping sandy carbonate facies. Of greater interest were the Pleistocene lacustrine clay and travertine deposits in the northwest part of the valley where the waters are of volcanic origin. There, clays contained as much as $1,500 \mathrm{ppm}$ lithium; travertine or lacustrine limestones, as much as $700 \mathrm{ppm}$; and plants, a maximum of $300 \mathrm{ppm}$ lithium. The area appears to be favorable for the commercial production of lithium salts.

The carbonates with the highest concentrations of lithium are clearly of biochemical origin (figs. $3,4,5$ ) and probably reflect selective transpiration of particular elements by halophytes. Lithium has been shown to substitute for magnesium in the crystal lattice of the clays. Clays deposited or formed in saline lacustrine deposits commonly have relatively high lithium contents. Studies by P. D. Blackmon and H. C. Starkey (written commun., 1974) at the Pleistocene Lake Tecopa in the southern part of the Amargosa Desert showed the zeolitic rocks to contain 50-100 ppm lithium and montmorillonitic claystones to contain $100-800 \mathrm{ppm}$. A nearly pure separate of saponite from a claystone contained $0-34$ percent lithium oxide.

\section{OTHER CLOSED BASINS}

Lithium and potassium have been commercially produced in Owens Lake and are being produced in Clayton Valley; halite, calcium chloride, and gypsum are being mined in Bristol Lake, and halite is being recovered at Fourmile Flat. In all these evaporite basins the brines are pumped from depth and evaporated to crystallize the salts. Lithium chloride and potassium are or have been produced from the remaining mother liquor in Owens Lake and Clayton Valley. Hectorite, a lithium clay, is being 
TABLE 10.-Percentage of lithium and associated ions in sediments and ash of plants from Amargosa Desert, Nevada and California [Stations shown in fig. 1. Analysts are named in introduction. N, not determined; X, xerophyte; P, phreatophyte; Ha, halophyte; WSS, water-soluble salts. The soil in which the sampled plant grew is listed directly below each plant]

\begin{tabular}{|c|c|c|c|c|c|c|c|c|c|c|c|c|c|c|c|c|c|c|c|}
\hline \multirow[t]{2}{*}{$\begin{array}{l}\text { Sta- } \\
\text { tion } \\
\text { No. }\end{array}$} & \multirow[t]{2}{*}{ Sample } & \multirow[t]{2}{*}{$\begin{array}{l}\text { Lab. } \\
\text { No. } \\
\text { (D-) }\end{array}$} & \multirow{2}{*}{\multicolumn{2}{|c|}{$\begin{array}{l}\text { Ash WSS } \\
\text { (percent) }\end{array}$}} & \multicolumn{2}{|c|}{ Lithium } & \multicolumn{2}{|c|}{ Magnesium } & \multicolumn{2}{|c|}{ Calcium } & \multicolumn{2}{|c|}{ Sodium } & \multicolumn{2}{|c|}{ Potassium } & \multicolumn{2}{|c|}{ Boron } & \multirow{2}{*}{$\begin{array}{c}\text { Carbo- } \\
\text { nate } \\
\text { (as } \\
\left.\mathrm{CO}_{2}\right) \\
\text { Soil }\end{array}$} & \multicolumn{2}{|c|}{$\begin{array}{l}\text { Sulfate } \\
\text { (water- } \\
\text { soluble) }\end{array}$} \\
\hline & & & & & Plant & Soil & Plant & Soil & Plant & Soil & Plant & Soil & Plant & Soil & Plant & Soil & & Plant & Soil \\
\hline & & & Clay $\mathrm{F}$ & its $\mathrm{N} O$ & $f$ Death & Valley & function, & from As & h Tree & Spring & to $\mathrm{ESE}$, & $\mathrm{Na}_{2} \mathrm{HCO}$ & 3 grour & water & & & & & \\
\hline \multirow[t]{2}{*}{ A5 } & $\begin{array}{l}\text { Lake clay with root } \\
\text { casts-- } \\
\text { Limestone of bio- }\end{array}$ & 403349 & --- & 0.25 & ------ & 0.15 & $\cdots$ & 11.0 & ---- & 0.92 & ----- & 1.1 & ---- & 1.7 & ----- & 0.01 & 0.04 & --- & 0.04 \\
\hline & $\begin{array}{l}\text { genic origin-- } \\
\text { Atriplex spinifera }\end{array}$ & 412759 & ---- & .48 & $-\cdots$ & .07 & ----- & 3.0 & ---- & 42.0 & ----- & .2 & ---- & .1 & $-\cdots$ & $\mathrm{N}$ & --.-- & +- & .09 \\
\hline \multirow{8}{*}{ A5e. } & (R) $-1-$ & 408130 & 10.7 & --- & 0.015 & ----- & 7.0 & $\ldots$ & 25 & $-\cdots$ & 4.3 & ---- & 3.7 & -- & 0.02 & $-\cdots$ & ---- & 0.12 & $-\cdots$ \\
\hline & Pinkish limestone--- & 408171 & --- & 1.46 & ------ & .03 & ---- & 1.9 & ---- & 32.6 & ---- & .47 & ---- & .27 & --- & .003 & 36.9 & --- & .26 \\
\hline & $\begin{array}{l}\text { Lepidium fremonti-- } \\
\text { Casts on roots--- }\end{array}$ & $\begin{array}{l}408131 \\
408172\end{array}$ & $\begin{array}{l}10.4 \\
---\end{array}$ & 1.02 & $\begin{array}{r}.0075 \\
---.-\end{array}$ & .03 & 3.0 & 2.7 & $\begin{array}{l}14 \\
--\end{array}$ & 12.4 & $\begin{array}{l}3.7 \\
-\cdots-\end{array}$ & .96 & 19.4 & 2.4 & $\begin{array}{c}.07 \\
---.\end{array}$ & .03 & 12.6 & $\begin{array}{l}1.64 \\
-\cdots-\end{array}$ & .36 \\
\hline & Brown sulfate zone & & & & & & & & & & & & & & & .05 & 12.0 & & 00 \\
\hline & $\begin{array}{l}\text { with crust--- } \\
\text { Cleomella obtusi-- }\end{array}$ & 408173 & --- & 11.0 & ----- & .02 & ------ & 2.1 & ---- & 2.9 & $-\cdots$ & 6.4 & $-\cdots-$ & 3.7 & ----- & .1 & 5.9 & --- & 2.58 \\
\hline & folia (Ha)- & 413089 & 9.0 & $--\infty$ & .015 & ----- & 5.0 & --- & 6.6 & ---- & 10 & ----- & 18 & ----- & .03 & ---- & ----- & 1.2 & --- \\
\hline & Calcareous soil----- & 413122 & --- & .02 & ------ & .015 & ------ & 3.0 & ---- & 32.0 & ---- & .11 & ---- & .35 & $-\cdots$ & .005 & ----- & --- & .02 \\
\hline & Sulfate soil-- & 413123 & -- & 2.3 & ---- & .028 & ----- & 5.0 & --- & 5.7 & ----- & 2.2 & ---- & 2.7 & ---- & .02 & --- & --- & 2.3 \\
\hline \multirow[t]{6}{*}{ A5B } & $\begin{array}{l}\text { Drstrchlis stricta } \\
\text { (P) }\end{array}$ & 408640 & 15.8 & --- & .006 & --- & .7 & ----- & 1.3 & ---- & 7.8 & ---- & 2.2 & ----- & .03 & ---- & $-\cdots$ & .14 & --- \\
\hline & Sporobolus airoides & & & & & & & & & & & & & & & & & & \\
\hline & $\begin{array}{l}\text { (Ha)-x pentandra } \\
\text { Tamarix }\end{array}$ & 408641 & 15.8 & ---- & .008 & ---- & 1.0 & --- & 2.3 & --- & 6.8 & ---- & 1.7 & $+\cdots$ & .02 & ----- & ----- & .36 & --- \\
\hline & $\begin{array}{l}(\mathrm{P}) \\
\text { Calcareous lake }\end{array}$ & 408642 & 14.5 & ---- & .03 & ----- & $>10$ & --- & 14.8 & ---- & 10.3 & --.- & 5.6 & ----- & .05 & ---- & $\cdots$ & 2.3 & ---- \\
\hline & $\begin{array}{l}\text { clay } \\
\text { Limestone of bio- }\end{array}$ & 418525 & --- & .18 & ----- & .039 & ----- & .96 & ----- & 9.9 & ----- & 1.7 & ----- & 2.2 & ---- & .015 & 21.2 & ---- & .03 \\
\hline & genic origin & 118526 & --- & .28 & ---- & .05 & ----- & .33 & ---- & 38.3 & ----- & .06 & ---- & .15 & ----- & $<.002$ & 35.4 & ---- & .08 \\
\hline
\end{tabular}

Death Valley Junction, near spring

\begin{tabular}{|c|c|c|c|c|c|c|c|c|c|c|c|c|c|c|c|c|c|c|c|}
\hline \multirow[t]{3}{*}{ A10 } & $\begin{array}{l}\text { Tamarix pentandra } \\
(\mathrm{P})^{2}-\mathrm{a} \\
\text { Hymenoclea salsola }\end{array}$ & 412756 & 6.9 & ----- & 0.02 & ---- & 7.0 & --- & 8.4 & ----- & 12 & ---- & 19 & ---- & 0.07 & ---- & ---- & 1.5 & -- \\
\hline & $\begin{array}{l}\text { (P) }{ }^{3}- \\
\text { Atriplex parryi (X) }\end{array}$ & $\begin{array}{l}412757 \\
413088\end{array}$ & $\begin{array}{l}21.4 \\
25.0\end{array}$ & ---- & $\begin{array}{l}.02 \\
.02\end{array}$ & ---- & $\begin{array}{l}1.5 \\
1.5\end{array}$ & ----- & $\begin{array}{l}1.4 \\
4.6\end{array}$ & ----- & $\begin{array}{l}32 \\
25\end{array}$ & ----- & $\begin{array}{l}8 \\
3.4\end{array}$ & ----- & $\begin{array}{l}.015 \\
.20\end{array}$ & ---- & ---- & $\begin{array}{l}1.4 \\
.54\end{array}$ & --- \\
\hline & Sandy soil- & 413121 & --- & 0.50 & 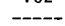 & 0.017 & -...- & 3.0 &.--- & 6.0 & $\ldots$ & 3.3 & $--\cdots$ & 2.7 & ---- & 0.20 & -..- & -- & 0.50 \\
\hline
\end{tabular}

Playa NE of Allens Well (no vegetation)

\begin{tabular}{|c|c|c|c|c|c|c|c|c|c|c|c|c|c|c|c|c|c|c|c|}
\hline A4 & $\begin{array}{l}\text { Brown carbonate } \\
\text { layer with NaCl--- } \\
\text { Salt crust---- }\end{array}$ & $\begin{array}{l}403347 \\
403348\end{array}$ & --- & $\begin{array}{r}2.0 \\
80.6\end{array}$ & ---- & $\stackrel{0.015}{\mathrm{~N}}$ & ----- & $\begin{array}{r}3.4 \\
.4\end{array}$ & ----- & $\begin{array}{l}8.7 \\
.78\end{array}$ & ----- & 29 & ----- & $\begin{array}{l}2.7 \\
3.2\end{array}$ & ---- & $\begin{array}{c}0.015 \\
.05\end{array}$ & $\begin{array}{r}10.2 \\
9.4\end{array}$ & --- & $\begin{array}{l}0.41 \\
19.5\end{array}$ \\
\hline & & & & Playa $N$ & E of Ash & Meadows & ; ground & water a & $5-6 \mathrm{f}$ & $t(1.5-$ & $-1.8 \mathrm{~m})$, & CaMgHC & $\left.\mathrm{O}_{3}\right)$ & & & & & & \\
\hline \multirow[t]{5}{*}{ Al } & $\begin{array}{l}\text { A triplex parryi }(\mathrm{X})- \\
\text { A. confertifolia }\end{array}$ & 403652 & 21.6 & ---- & 0.005 & --- & 0.005 & $-\cdots$ & 5.0 & ---- & 17.6 & ---- & 16.8 & ---- & 0.007 & ---- & ---- & 0.12 & --- \\
\hline & $\begin{array}{l}\text { (X) } \\
\text { Sandy soil at sta. }\end{array}$ & 403653 & 16.3 & ---- & .01 & --- & .01 & ---- & 7.0 & ---- & 19.2 & ---- & 12.4 & ---- & .007 & ---- & ---- & .24 & ---- \\
\hline & NE of playa-- & 403343 & --- & 0.20 & ---- & 0.005 & ----- & 1.1 & ----- & 4.5 & ----- & 1.7 & ---- & 2.3 & --- & 0.003 & 4.4 & --- & 0.01 \\
\hline & Atriplex parryi (X)- & 413087 & 27.0 & ---- & .015 & $-\cdots$ & 3.0 & ---- & 8.8 & ---- & 15 & ---- & 8.4 & ---- & .02 & ---- & $-\cdots$ & .15 & --- \\
\hline & Sandy soil-- & 413120 & ---- & ---- & --- & .0035 & ----- & 1.5 & ---- & 4.3 & ---- & 1.3 & $-\cdots$ & 12.4 & $-\cdots$ & .003 & ---- & --- & $<.01$ \\
\hline \multirow[t]{2}{*}{ A2 } & $\begin{array}{l}\text { P1aya crust-- } \\
\text { Playa at } 6 \text { inches }\end{array}$ & 403344 & ---- & 1.5 & ---- & .007 & ---- & 3.2 & ----- & 7.0 & ----- & 2.3 & ---- & 2.6 & ----- & .015 & 7.8 & ---- & 1.13 \\
\hline & $\begin{array}{l}\text { (15 } \mathrm{cm}) \text { depth----- } \\
\text { Suaeda ramossissima }\end{array}$ & 403345 & --- & 1.5 & ----- & .015 & ------ & 3.2 & $\cdots$ & 4.8 & -n..- & 7.4 & ----- & 2.5 & ---- & .03 & 10.4 & --- & .95 \\
\hline \multirow{5}{*}{ A3 } & $\begin{array}{c}\text { (P) } \\
\text { Atriplex conferti- }\end{array}$ & 403654 & 22.0 & ---- & .01 & ----- & 2.0 & --- & 4.1 & $-\cdots$ & 27.9 & $--\cdots$ & 8.3 & ----- & .015 & ---- & ---- & .72 & ---- \\
\hline & $\begin{array}{l}\text { folia }(\mathrm{X})- \\
\text { Carbonate clay with }\end{array}$ & 411477 & 38.6 & ----- & .0035 & $-\cdots$ & 1.5 & ----- & 6.5 & ---- & 21 & --- & 17.0 & ----- & .01 & ---- & ----- & ---- & --- \\
\hline & $\begin{array}{r}\mathrm{SO}_{4}- \\
\text { Ef f lorescence--- }\end{array}$ & $\begin{array}{l}403346 \\
411455\end{array}$ & ---- & $\begin{array}{l}.02 \\
.01\end{array}$ & ----- & $\begin{array}{l}.02 \\
.01\end{array}$ & ----- & $\begin{array}{l}4.8 \\
3.0\end{array}$ & ---- & $\begin{array}{l}8.4 \\
5.8\end{array}$ & --- & 6.9 & ----- & $\begin{array}{l}2.2 \\
1.7\end{array}$ & ----- & .03 & 15.2 & ---- & 3.65 \\
\hline & & 411433 & & & - & & $-x$ & & & & 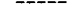 & 10.0 & 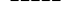 & & $\cdots$ & .05 & ---- & --- & $\cdots$ \\
\hline & & & & & & Fairbank & is Spring, & mixed & $\mathrm{CaMgHCO}$ & 3 and $N$ & $\mathrm{Na}_{2} \mathrm{HCO}_{3}$ & & & & & & & & \\
\hline \multirow[t]{4}{*}{ A6 } & $\begin{array}{l}\text { Tamarix pentandra } \\
\text { (P) }\end{array}$ & 403655 & 9.5 & --- & 0.0065 & $m$ & 5.0 & ----- & 13.3 & ---- & 1.6 & ----- & 16.8 & ----- & 0.03 & ---- & ----- & 1.4 & ---- \\
\hline & $\begin{array}{l}\text { Hard white calcare- } \\
\text { ous clay-- } \\
\text { Brown silty carbo- }\end{array}$ & 403350 & --- & 0.45 & ----- & 0.005 & ------ & 0.96 & ---- & 9.9 & ---- & 1.7 & ----- & 2.2 & $-\cdots$ & 0.003 & 9.6 & $-\cdots$ & 0.10 \\
\hline & nate interbedded-- & 403351 & --- & .15 & ---- & $\mathrm{N}$ & $-\cdots$ & 3.3 & ----- & 38.3 & ----- & .06 & ----- & .15 & --- & $<.002$ & 42.5 & ---- & .01 \\
\hline & & & & & McG & ilivrays & Spring, & $\mathrm{CaMgHCO}$ & $\mathrm{O}_{3}$, rech & large in & a limest & one & & & & & & & \\
\hline \multirow[t]{2}{*}{ A7 } & $\begin{array}{l}\text { Bacharis glutinosa } \\
\text { (P)- }\end{array}$ & 411478 & 10.0 & ---- & 0.015 & ----- & $>10$ & ----- & 23 & ----- & 0.91 & ----- & 6.6 & ----- & 0.15 & ---- & --- & --- & ---- \\
\hline & Black organic mud--- & 411456 & $-\cdots$ & ---- & $-\cdots$ & 0.015 & $-\cdots$ & 2.0 & - & 10 & $-\cdots$ & 1.1 & ---- & 1.5 & --- & 0.005 & 6 & ---- & ---- \\
\hline \multicolumn{20}{|c|}{ Spring at trailer, $\mathrm{CaMgHCO}_{3}$, recharge in limestone } \\
\hline \multirow[t]{3}{*}{ A8 } & $\begin{array}{l}\text { Tamarix pentranda } \\
\text { (P) }\end{array}$ & 411480 & 11.4 & ----- & 0.01 & ----- & 7.0 & ---- & 14 & ----- & 16 & ---- & 9.0 & ----- & 0.05 & ----- & -..-- & --- & --- \\
\hline & Black organic mud--- & 411457 & --- & ----- & --- & 0.0045 & $-\cdots$ & 1.5 & ---- & 19 & $-\cdots$ & 2.2 & ---- & 1.5 & --- & 0.002 & ----- & ---- & --- \\
\hline & & & & & Point & of Rock & spring, & CaMgHC & $\mathrm{CO}_{3}$, rec & harge & in limes & tone & & & & & & & \\
\hline \multirow[t]{2}{*}{ A9 } & $\begin{array}{l}\text { Pluchea sericea (P)- } \\
\text { Calcareous tufa--N-- }\end{array}$ & $\begin{array}{l}411479 \\
411458\end{array}$ & 8.3 & --- & 0.03 & ---- & 3.0 & ----- & 14 & $-\cdots$ & 16 & ---- & 9.0 & $-\cdots$ & 0.15 & --- & ---- & --- & ---- \\
\hline & Calcareous tufa----- & 411458 & $\cdots$ & ---- & -.--- & 0.0025 & ----- & 2.0 &.--- & 37 & $-\cdots+\infty$ & 0.15 & --- & 0.2 & $-\cdots$ & $<0.002$ & $-\cdots$ & --- & $\cdots$ \\
\hline
\end{tabular}

${ }^{1}$ Chlorine content of soil 0.09 percent. $\quad{ }^{2}$ Fluorine content of plant 0.0140 percent.

${ }^{3}$ Fluorine content of plant 0.0116 percent. 
TABLE 11.-Percentage of lithium and associated ions in sediments and the ash of plants from three closed basins in which economic quantities of lithium occur

[Stations shown in fig. 1. Analysts are named in introduction. P, phyteatophyte; Ha, halophyte; X, xerophyte; Hy, hydrophyte; WSS, water-soluble salts. The soil in which the sampled plant grew is listed directly below each plant]

\begin{tabular}{|c|c|c|c|c|c|c|c|c|c|c|c|c|c|c|c|c|c|c|c|c|}
\hline \multirow{2}{*}{$\begin{array}{l}\text { Sta- } \\
\text { tion } \\
\text { No. } \\
\end{array}$} & \multirow[t]{2}{*}{ Sample } & \multirow{2}{*}{$\begin{array}{l}\text { Lab. } \\
\text { No.; } \\
\text { (D-) }\end{array}$} & \multirow[t]{2}{*}{ Ash } & \multirow[t]{2}{*}{ WSS } & \multicolumn{2}{|c|}{ Li thium } & \multicolumn{2}{|c|}{ Magnes ium } & \multicolumn{2}{|c|}{ Calcium } & \multicolumn{2}{|c|}{ Sodium } & \multicolumn{2}{|c|}{ Potassium } & \multicolumn{2}{|c|}{ Boron } & \multicolumn{2}{|c|}{$\begin{array}{r}\text { Carbonate } \\
\left(\text { as } \mathrm{CO}_{2}\right) \\
\end{array}$} & \multicolumn{2}{|c|}{$\begin{array}{r}\text { Sulfate } \\
\text { (water- } \\
\text { soluble) } \\
\end{array}$} \\
\hline & & & & & Plant & Soil & Plant & Soil & Plant & Soil & Plant & Soil & Plant & Soil & Plant & Soil & Plant & Soil & Plant & Soi 1 \\
\hline & & $\mathrm{Cl}$ & $y$ ton & alley ( & (Lithiu & $\mathrm{m}$ and $\mathrm{p}$ & potass: & um prod & duced $c$ & ommerc & ally $f$ & rom $\mathrm{ch}$ & Loride & brines ) & & & & & & \\
\hline L3 & Sarcobatus vermiculatus & & & & & & & & & & & & & & & & & & & \\
\hline & (P) (P) & 408134 & 12.7 & -- & 0.07 & $-\cdots$ & 0.5 & --- & 6.8 & -- & 23.2 & $-\cdots$ & 14.6 & --- & 0.015 & ---- & ---- & ---- & 0.38 & $\cdots$ \\
\hline & Sulfate soil under plant & 408177 & $\rightarrow$ & 13.3 & --- & 0.03 & $\cdots$ & 1.4 & $-m--$ & 6.8 & --- & 4.7 & $-\cdots$ & 2.57 & $\cdots$ & 0.015 & ---- & 1.6 & $-\cdots$ & 2.33 \\
\hline & Spongy chloride sor 1---- & 408178 & --- & 13.8 & --- & .03 & --- & 1.4 & --- & 3.0 & ---- & 6.1 & --- & 2,24 & --- & .02 & $-\cdots$ & 1.6 & ---- & 1.22 \\
\hline & Efflorescent crust----- & 408179 & --- & 88.6 & --- & .03 & $\cdots$ & .24 & --- & 1.8 & --- & 35.0 & --- & 1.3 & --- & $<.02$ & --- & .18 & $3---$ & 3.02 \\
\hline L4A & Soft brown lake clay & & & & & & & & & & & & & & & & & & & \\
\hline & (no plants)-- & 415459 & --- & 2.8 & --- & .03 & $-m$ & 1.0 & --- & 3.3 & --- & 2.9 & -- & 3.2 & --- & .015 & $m$ & --- & --- & .10 \\
\hline & White efflores cent crust & 415460 & $-\infty$ & 3.2 & --- & .05 & --- & 1.5 & --- & 3.3 & $-\cdots$ & 2.8 & --- & 2.8 & --- & .015 & $-\cdots$ & ---- & --- & .24 \\
\hline L4B & Allenrolfea occidentalis & & & & & & & & & & & & & & & & & & & \\
\hline & (Ha) - & 408135 & 25.8 & ---- & .15 & --- & 1.0 & --- & 3.6 & ---- & 31.5 & --- & 4.5 & ---- & .05 & --- & --- & -- & 2.08 & $\rightarrow$ \\
\hline & Juncus cooperi (Hy)----- & 408136 & 6.2 & ---- & .30 & --- & 1.0 & ---- & 4.6 & --- & 21.6 & --- & 4.8 & --- & .2 & ---- & --- & --- & .4 & ---- \\
\hline & Algae in hot spring (Hy) & 408148 & 83.8 & --- & .03 & --- & .3 & --- & 33.4 & --- & 3.6 & --- & 3.6 & --- & .007 & --- & --- & --- & --- & $-\cdots-$ \\
\hline & Spring deposit between & & & & & & & & & & & & & & & & & & & \\
\hline & Juncus---------- & 408180 & --- & 7.45 & --- & .03 & --- & .7 & --- & 30. & --- & 3.0 & $-\infty$ & 3.0 & --- & .01 & --- & 34.1 & -- & .50 \\
\hline & Spring deposit under & & & & & & & & & & & & & & & & & & & \\
\hline & Juncus------------ & 408181 & --- & 9.51 & --- & .05 & --- & 1.0 & --- & 25. & --- & 3.0 & --- & 3.0 & --- & .02 & --- & 25.6 & --- & 2.51 \\
\hline & Allenrolfea occidentalis & & & & & & & & & & & & & & & & & & & \\
\hline & (Ha)--_- & 413056 & 44. & --- & .3 & $\cdots$ & 2.0 & --- & 1.4 & --- & 31. & --- & 3.4 & --- & .07 & --- & -- & --- & 3.4 & --- \\
\hline & Hot spring mud-- & 413101 & --- & ---- & --- & .01 & ---- & 1.0 & ---- & 23. & --- & 1.0 & ---- & .85 & --- & .007 & --- & $-\infty$ & --- & .18 \\
\hline L18 & Allenrolfea occidentalis & & & & & & & & & & & & & & & & & & & \\
\hline & (Ha) -- & 413057 & 33. & ---- & .3 & --- & 3.0 & --- & 1.0 & $\cdots$ & 29. & $m$ & 3.0 & nam- & .05 & --- & $\rightarrow$ & -- & 1.8 & $-\infty$ \\
\hline & Brown soft soil with & & & & & & & & & & & & & & & & & & & \\
\hline & $\mathrm{NaCl}$ & 413102 & $\rightarrow$ & --- & --- & .03 & --- & 2.0 & --- & 3.9 & --- & 2.1 & $-\infty$ & 2.4 & --- & .015 & --- & --- & --- & .16 \\
\hline & & & & & wens Lal & ke (Lit & thium & ind pota & assium & former & ly prod & luced $\mathrm{fr}_{\mathrm{r}}$ & rom $\mathrm{chl}$ & oride b & brines) & & & & & \\
\hline L12 & Scirpus olneyi (Hy) & 411481 & 15.5 & $--a$ & 0.035 & -- & 1.5 & $-\cdots$ & 4.2 & $-\rightarrow-$ & 15. & $-\cdots$ & 13. & --- & 0.7 & --- & --- & --- & $-\cdots$ & $\cdots$ \\
\hline & Mud in spring at playa & & & & & & & & & & & & & & & & & & & \\
\hline & 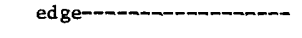 & 411459 & -- & --- & $-\cdots$ & 0.01 & $\cdots$ & 1.5 & --- & 7.8 & --- & 1.45 & --- & 2.5 & --- & 0.007 & --- & -- & --- & 0.65 \\
\hline & Atriplex torreyi (X)- & 411534 & 20.4 & - & .05 & ---- & .7 & --- & 3.2 & $m$ & 26. & $\cdots$ & 11. & $-m$ & .03 & 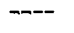 & -- & -- & 2.2 & $\rightarrow$ \\
\hline & Sand at edge of playam- & 126550 & $m$ & --- & --- & .007 & --- & 1.5 & --- & 7.4 & --- & 3. & $\cdots$ & 2.0 & $--m$ & .03 & --- & --- & $-\cdots$ & -- \\
\hline & Suaeda torreyana (P) & 413054 & 24.0 & -- & .07 & --- & 3.0 & ---- & 1.4 & --- & 26. & --- & 8.2 & --- & .03 & $m$ & $m$ & --- & 2.2 & $-\rightarrow$ \\
\hline L19 & Distichlis spicata (P)-- & 413091 & 15.0 & $-m$ & .10 & ---- & 1.5 & --- & 2.0 & --- & 18. & $\cdots$ & 3.0 & $-\cdots$ & .15 & --- & -- & -- &, 19 & --- \\
\hline & Soil under evaporites & & & & & & & & & & & & & & & & & & & \\
\hline & in evaporating pan-- & 413098 & 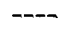 & --- & --- & .012 & --- & 3.0 & ---- & 9.2 & -- & 2. & --- & 1.9 & --- & .015 & $-\infty$ & -- & $\rightarrow$ & .12 \\
\hline & Evaporites being & & & & & & & & & & & & & & & & & & & \\
\hline & shipped for $B^{1}+-$ & 413099 & $\rightarrow$ & --- & --- & .07 & --- & 3.0 & --- & 6.1 & --- & 17 & --- & .85 & --- & .05 & $-\cdots$ & --- & --- & .76 \\
\hline L19B & Soft spring mud with & & & & & & & & & & & & & & & & & & & \\
\hline & 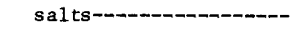 & 415469 & --- & 1.8 & -- & .08 & --- & 3.0 & $-\infty-$ & 11.0 & --- & 2.5 & $-\cdots$ & 1.9 & --- & .03 & --- & -- & $m$ & .15 \\
\hline L19A & Crystals in Distichlis & & & & & & & & & & & & & & & & & & & \\
\hline & plants-_-_-_-_-_- & 415468 & $-\cdots$ & 44. & --- & .01 & -- & 1.5 & --- & 3.5 & $-\cdots$ & 10 . & --- & 1.7 & ---- & .1 & $-\infty$ & $-n$ & ---1 & 15. \\
\hline & Spring mud with algal & & & & & & & & & & & & & & & & & & & \\
\hline & scum--n-n- & 415467 & -- & .7 & --- & .004 & $-\cdots$ & .7 & -- & 2.8 & --- & 2.8 & --- & 3.1 & $\cdots$ & .1 & --- & -- & -- & .17 \\
\hline & & & & & Hect & or (Lit & thium & ays be & eing mi & ned (t & ctor & e) ) & & & & & & & & \\
\hline L.24 & White carbonate lithium & & & & & & & & & & & & & & & & & & & \\
\hline & clay being shipped---- & 415473 & --- & 1.0 & ---- & 0.20 & $\rightarrow-$ & 7.0 & --- & 22. & --- & 1.1 & ---- & 0.24 & --- & 0.003 & --- & --- & --- & 0.01 \\
\hline & Darker clay surrounding & & & & & & & & & & & & & & & & & & & \\
\hline & white nodules------- & 415474 & --- & 1.6 & --- & .07 & --- & 3.0 & $-\cdots$ & 20. & --- & 1.5 & $-\cdots$ & .85 & $-\infty$ & .002 & --- & --- & --- & .03 \\
\hline & Shale underlying & & & & & & & & & & & & & & & & & & & \\
\hline & volcanic flow------- & 415476 & --- & .3 & --- & .005 & ---- & .3 & --- & .80 & ---- & 4.2 & --- & 2.4 & --- & .01 & ---- & -- & $\cdots$ & .01 \\
\hline
\end{tabular}

${ }^{1}$ Chlorine content of soil 1.4 percent.

mined in the Mohave Desert. Analyses of samples from three closed basins from which lithium has been produced are given in table 11 .
In Clayton Valley playa sediments consisting of 5-20 feet (1.5-6 m) of clay impregnated with halite and gypsum overlie beds of crystallized halite and saturated brine 
(Meinzer, 1917). Brines that contain 12 percent sodium and 3 percent potassium are currently being pumped by the Foote Mineral Co. from a depth of $500 \mathrm{ft}(150 \mathrm{~m})$. Lithium contents of the brine were not ascertained from company geologists, but a magnesium:lithium ratio of 1 was mentioned. The percentage of lithium in the brine can then be assumed from the available analyses for magnesium in the brines to be at least an order of magnitude higher than that of sediments sampled at the surface. The highest lithium value in a surface soil analyzed by the Foote Mineral Co. was $1,200 \mathrm{ppm}$. Our surface sediment samples averaged $300 \mathrm{ppm}$ lithium. Lithium-rich precipitate around the roots of Juncus in the hot spring on the east side of Clayton Valley contained $500 \mathrm{ppm}$ lithium; a Juncus root crown (fig. 3) contained 3,000 ppm. Water-soluble sulfate has been concentrated from 0.50 percent in the spring mud to 2.51 percent in mud around the roots of a Juncus plant (sta. L4B). Hunt (1966, p. 34) reported 13 percent total $\mathrm{SO}_{4}$ in the ash of Juncus; the plant described above contained 0.4 percent water-soluble $\mathrm{SO}_{4}$.

The water of Owens Lake is a dense brine containing halite, soda, borax, and other salts. The dried residue analyzed by Stone and Eaton in 1905 contained 38.09 percent potassium, 1.62 percent lithium, and only 0.02 percent magnesium (Gale, 1915). The mother liquor still constitutes a large proportion of the mass, permeating the entire thickness of crystallizing salt.

Mud in the bottom of the old evaporating pans at Owens Lake contained only 120 ppm lithium; evaporite, which is dug and trucked only for boron payments, contained 500 ppm boron and $700 \mathrm{ppm}$ lithium. Plants collected at several stations contained 350 to $1,000 \mathrm{ppm}$ lithium.

A high-lithium clay, hectorite, is mined at Hector, east of Barstow from lake beds close to volcanic flows from Mount Pisgah (Foshag and Woodford, 1936). The pure mineral contains $1.1-1.2$ percent $\mathrm{Li}_{2} \mathrm{O}$. The material being shipped is a white talclike clay that occurs in nodules and contained, in our sample, 0.2 percent lithium. The surrounding impure clay matrix contained only 0.07 percent. The hectorite resembled structurally the clay being mined in Amargosa Desert (A5) and shown by our analyses to contain a considerable amount of lithium.

Analyses of samples from seven other closed basins are given in table 12. On the Bristol Lake playa, rock salt (sodium chloride) is mined by the Leslie Salt Co. from a 6to 7-foot-thick bed, which is covered by a similar thickness of mud over an area of about 4 square miles. In the recovery method, calcium chloride is precipitated from brines believed to be the mother liquor of the evaporative basin. The abundance of calcium chloride in this basin is unique for basins of the Basin and Range province. The calcium chloride is believed by Gale (1951) to have originated in the basaltic flows from Bagdad crater, which have in Holocene times separated Bristol Lake from Bag- dad Lake to the northwest. Lithium is not mentioned in Gale's report. Polygonal salt crust in evaporating pans sampled during our study (sta. L25) contained only 20 $\mathrm{ppm}$ lithium. A sample of the playa carbonate mud overlying the salt contained $300 \mathrm{ppm}$ lithium, and Atriplex linearis rooted in the carbonate near the toe of the volcanic flow contained $150 \mathrm{ppm}$. Gypsum and oolitic surface material 350 feet $(100 \mathrm{~m})$ onto the barren playa from the south edge also contained scant lithium. The surface alluvium at the south edge of the lake was low in lithium, but desertholly and cattle spinach collected there contained 300 ppm lithium.

On Sarcobatus Flat, the sediments of the soft brown carbonate zone that are impregnated with halite contained $300 \mathrm{ppm}$ lithium, but greasewood ash contained only $150 \mathrm{ppm}$. Lesser amounts in both plants and soils were found in samples from Fourmile Flat (where halite is mined), Big Smoky Valley, Railroad Valley, and Oasis Valley. Samples of gypsiferous sediments collected near an old borax works in Columbus Salt Marsh contained only $30 \mathrm{ppm}$ lithium but contained 10,000 ppm boron. Atriplex spinifera growing on them contained $150 \mathrm{ppm}$ lithium and $1,500 \mathrm{ppm}$ boron. The barren playa muds 500 feet $(150$ $\mathrm{m})$ beyond the borax works contained $280 \mathrm{ppm}$ lithium and $1,500 \mathrm{ppm}$ boron. Seemingly, lithium is not associated directly with halite and borates but has a rather spotty distribution pattern in the basins, owing to sources of volcanic activity, to thermal hot springs, to adsorption on clay, or to subsequent flooding and subsurface movement of the solutions.

\section{PLANT PROSPECTING}

The analysis of plants for assessing lithium contents in brines in the Great Basin might be a useful prospecting tool in those areas where brines occur at depth and surface soils are relatively low in lithium. The lithium contents of plants growing in two plant societies in closed basins may indicate lithium concentrations at depth. First, hot springs at the contact of alluvium with basin sediments are apparently dissolving lithium at depth and the hydrophytes, such as Scirpus olneyi and Juncus cooperi, are absorbing and concentrating large quantities of lithium in plant tissues. Second, phreatophytes, such as Allenrolfea, Distichlis, and Suaeda, that are tolerant of and absorb large quantities of sodium chloride and grow in the chloride and sulfate zones also are tolerant of and absorb large quantites of lithium chloride. Xerophytic species of Atriplex, even though they may be lithium accumulators, have shallow root systems adapted to collecting surface water rather than ground water and, therefore, do not reflect lithium deposits at depth.

No symptoms of lithium toxicity were identified in plants, nor were useful indicators identified. Lycium is definitely an accumulator of lithium and may even be an 
TABLE 12.-Percentage of lithium and associated ions in sediments and the ash of plants from other closed basins in Nevada and California [Stations shown in fig. 1. Analysts are named in introduction. N, not detected; P, phreatophyte; X, xerophyte; wSs, water-soluble salts. The soil in which the sampled plant grew is directly below each plant]

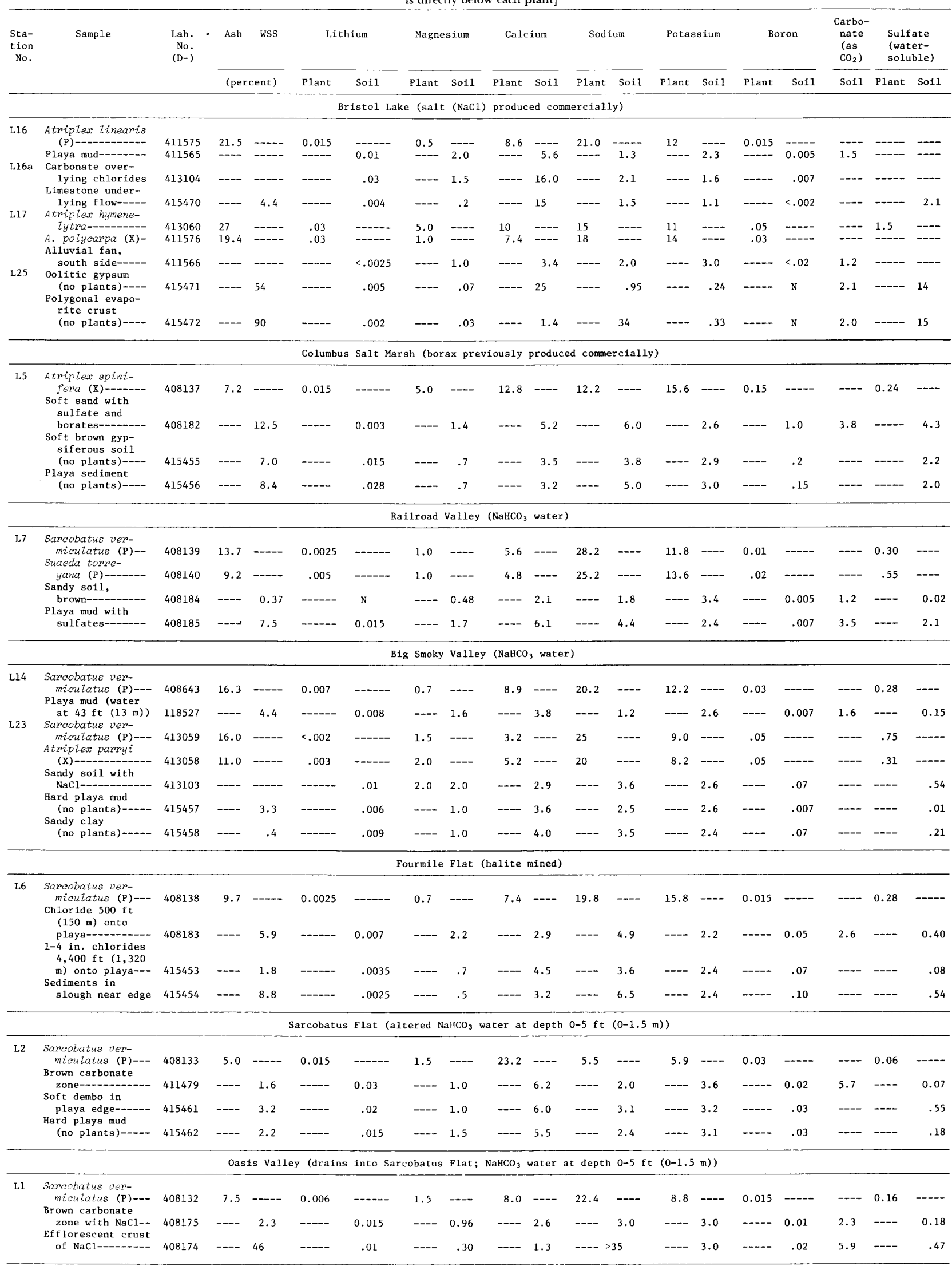


indicator of lithium but it cannot grow in soils of high salt (sodium chloride) content.

Plants would not be useful in prospecting for highpotassium brines, because nutrient elements, such as potassium, that are required by plants in large amounts in normal physiological processes are not generally accumulated to any great extent. The plant absorbs only the amount needed regardless of the amount in the soil unless the quantities available are extremely high. As the particular species of plants that grow in the chloride and sulfate zones use sodium in place of potassium even when the latter is available, no correlation between plant contents and brines would be expected.

\section{HEALTH ASPECTS OF LITHIUM}

Little is known concerning the long-term effects of lithium deficiency or excess on health or disease of domestic animals or man. Claims for the efficacy of lithium in the treatment of gout, diabetes, and epilepsy have not been substantiated. Probably the most promising use for lithium in medical practice arises from its profoundly tranquilizing effect on manicdepressive patients (Cade, 1949; Schou, 1959). In Texas, a strong negative correlation exists between lithiumintake, as indexed by concentrations in drinking water, and admission rates to State mental institutions (Dawson and others, 1970). According to Lawrence Razavi (written commun., 1970), lithium stabilizes chromosomes by shortening the amplitude of helical polymers, including DNA. Although the concentrations cannot be compared with those used in medical treatment, one might conclude that relatively high levels $(20-100 \mu \mathrm{g} / \mathrm{l})$ of lithium in drinking water as might be encountered in the Basin and Range province would be beneficial in improving chromosomal quality and cell membrane strength.

The well-known negative correlation between water hardness and cardiovascular mortality can be explained statistically by lithium concentrations concomitant with water hardness (Voors, 1971). Biological evidence that low levels of lithium provide a protective effect against atherosclerosis is accumulating.

No cases of toxicity from naturally occurring lithium have been reported; indeed, increasing evidence suggests several beneficial effects.

\section{SUMMARY}

Lithium contents average 22-655 ppm in igneous rocks, $17 \mathrm{ppm}$ in sandstone, $46 \mathrm{ppm}$ in shale, and $26 \mathrm{ppm}$ in limestone. During weathering, much of the released lithium is trapped in montmorillonitic clays; but lithium that reaches the sea tends to remain in solution as the highly soluble compound lithium chloride (average, $0.1 \mathrm{ppm}$ ). From 8 to $400 \mathrm{ppm}$ lithium have previously been reported in soils.
Both open and closed basins occur in the Basin and Range province; hydrologically closed basins are discharged by evapotranspiration, and open basins are discharged by underflow to basins of lower hydraulic head. The median lithium content for 100 major municipal water supplies of the United States is $2 \mu \mathrm{g} / \mathrm{l}$; that of 18 springs and wells of the Amargosa Desert, a closed basin, is $105 \mu \mathrm{g} / \mathrm{l}$. Thermal hot springs are a common source of lithium in geochemical processes, and more lithium is contained in sodium bicarbonate water originating in tuffs than in calcium-magnesium bicarbonate water originating in the Paleozoic limestones. A further concentration of lithium takes place by the evapotranspiration of brines contained in closed basins that drain a large recharge area and that were occupied by lakes in Pleistocene time. The percentages of lithium in the brines along with potassium, bromine, boron, and halite are of economic value in several areas. Further investigation of lacustrine clays in closed basins, particularly in the Amargosa Desert, may reveal lithium concentrations of economic value.

In an evaporative basin, lithium may remain in solution until a late stage and then be precipitated along with sodium, potassium, and boron in the chloride and sulfate zones, although lithium is readily adsorbed by clay minerals in lacustrine deposits and also precipitated in marls of biogenous origin. Sediments collected for our project contained maximum values of 70-2,000 ppm lithium in 12 closed basins and maximum values of $40-150 \mathrm{ppm}$ in 8 open basins.

Median contents of lithium in the type of sediments in closed basins were: lacustrine clays 700 ppm lithium; hotspring travertines $450 \mathrm{ppm}$; sulfate-chloride, and carbonate zones, $150 \mathrm{ppm}$; playa clay, $150 \mathrm{ppm}$; and alluvium, 30 ppm. Lithium may be concentrated in amounts greater than $1,000 \mathrm{ppm}$ in hot-spring deposits where lithium is dissolved at depth, pumped to the surface, and precipitated around the roots of hydrophytes.

Lithium is reported to be toxic to most cultivated plants at concentrations as low as $30 \mathrm{ppm}$ in the soil, and for citrus plants, as low as $12 \mathrm{ppm}$. Vegetation generally contains about $1 \mathrm{ppm}$ lithium in the dry weight; a maximum concentration of $4,400 \mathrm{ppm}$ has been reported in the ash (or $\pm 750 \mathrm{ppm}$ in dry weight) of healthy tobacco. In the Great Basin, pickleweed and rush containing 3,000 ppm in the ash grow without apparent damage in soils containing 300-500 ppm lithium. A median of $150 \mathrm{ppm}$ in the ash or $22.8 \mathrm{ppm}$ in dry weight of higher plants collected from these basins is considerably greater than the average of $1.3 \mathrm{ppm}$ in dry weight found by Bertrand.

The lithium content in the vegetation correlates well with that of the soil (as shown in fig. 2) except at levels of less than $100 \mathrm{ppm}$; at lower levels, the greater relative content in plants suggests that lithium is essential to plants. The species of plants that accumulate the greatest 
amounts of lithium are largely from the Chenopodiaceae family, and most lithium accumulators also take up large amounts of sodium chloride. The analysis of hydrophytes in springs at the alluvium-basin sediment contact and of halophytes growing in the chloride and sulfate zones of closed basins may be useful in evaluating the economic possibility of lithium extraction from brines.

The high lithium concentrations in water and vegetation of hydrologically closed basins may have a beneficial effect on the health of both lower animals and people living in the Basin and Range province.

\section{REFERENCES CITED}

Bear, F. E., ed., 1964, Chemistry of the soil [2d ed.]: Am. Chem. Soc. Mon. 160,515 p.

Bertrand, Didier, 1952, Sur la répartition du lithium chez les Phanérogames [The distribution of lithium in the phanerogams]: Acad. Sci. Comptes Rendus, v. 234, p. 2102-2104.

1959, Nouvelles recherches sur la répartition du lithium chez les Phanerogames [New investigations on the distribution of lithium in the phanérogams]: Acad. Sci. Comptes Rendus, v. 249, pt. 1, p. 787-788.

Borovik-Romanova, T. F., 1965, The content of lithium in plants, in Khitarov, N. I., ed., Problems of geochemistry [in Russian]: Akad. Nauk SSSR Inst. Geokhimii i Analiticheskoi Khimii; translated into English in Jerusalem, Israel Program for Sci. Translations, 1969.

Bradford, G. B., 1966, Lithium, Chap. 17, in Chapman, H. D., ed., Diagnostic criteria for plants and soils: Berkeley, California Univ., Div. Agr. Sci., Agr. Expt. Sta., p. 218-223.

Brownell, P. F., 1965, Sodium as an essential micronutrient element for a higher plant (Atriplex vesicaria): Plant Physiology, v. 40, p. $460-468$.

Cade, J. F. J., 1949, Lithium salts in the treatment of psychotic excitement: Med. Jour. Australia, v. 2, p. 349-352.

Dawson, E. B., Moore, T. D., and McGanity, W. J., 1970, The mathematical relationship of drinking water, lithium, and rainfall to mental hospital admission: Diseases of the Nervous System, v. 31, p. 811-820.

Durfor, C. N., and Becker, Edith, 1964, Public water supplies of the 100 largest cities in the United States, 1962: U.S. Geol. Survey Water-Supply Paper 1812, 364 p.

Eakin, T. E., 1963, Ground-water appraisal of Dry Lake and Delamar Valleys, Lincoln County, Nevada: Nevada Dept. Conserv. and Nat. Resources Ground-Water Resources-Reconn. Ser. Rept. 16, 26 p.

Eakin, T. E., Schoff, S. L., and Cohen, Philip, 1963, Regional hydrology of a part of southern Nevada-A reconnaissance: U.S. Geol. Survey open-file report, $40 \mathrm{p}$.

Edwards, J. D., 1941, Cytological studies of toxicity in meristem cells of the roots of Zea mays: South Dakota Acad. Sci. Proc., v. 21, p. 65-67.

Epstein, Emanuel, 1960, Calcium-lithium competition in absorption by plant roots: Nature, v. 185, no. 4714, p. 705-706.

Evans, H. J., and Sorger, G. L., 1966, Role of mineral elements with emphasis on the univalent cations: Ann. Rev. Plant Physiology, v. 17 , p. $47-76$.

Foshag, W. F., and Woodford, A. O., 1936, Bentonitic magnesian clay mineral from California: Am. Mineralogist, v. 21, no. 4, p. 238-244.

Gale, H. S., 1915, Salines in the Owens, Searles, and Panamint basins, southeastern California: U.S. Geol. Survey Bull. 580-L, p. 251-323. 1951, Geology of the saline deposits, Bristol Dry Lake, San
Bernardino County, California: California Div. Mines Spec. Rept. $13,21 \mathrm{p}$.

Headden, W. P., 1921, Titanium, barium, strontium and lithium in certain plants: Colorado Agr. Expt. Sta. Bull. 267, 20 p.

Hunt, C. B., 1966, Plant ecology of Death Valley, California, with a section on Distribution of fungi and algae, by C. B. Hunt and L. W. Durrell: U.S. Geol. Survey Prof. Paper 509, 68 p.

Hunt, C. B., and Robinson, T. W., 1969, Possible interbasin circulation of ground water in the southern part of the Great Basin, in Geological Survey research 1960: U.S. Geol. Survey Prof. Paper 400-B, p. B273-B274.

Hunt, C. B., Robinson, T. W., Bowles, W. A., and Washburn, A. L., 1966, Hydrologic basin, Death Valley, California: U.S. Geol. Survey Prof. Paper 494-B, 138 p.

Johnson, M. S., and Hibbard, D. E., 1957, Geology of the Atomic Energy Commission Nevada proving grounds area, Nevada: U.S. Gieol. Survey Bull. 1021-K, p. 333-384.

Jones, B. F., 1966, Geochemical evolution of closed basin water in the western Great Basin, in Symposium on salt, 2d, Geology, geochemistry, mining, v. 1: Cleveland, Ohio, Northern Ohio Geol. Soc., p. 181-200.

Kent, N. L., 1941, Absorption, translocation, and ultimate fate of lithium in the wheat plant: New Phytologist, v. 40, p. 291-298.

Linstow, O. von, 1929, Bodenanzeigende Pflanzen [Soil-indicating plants] [2d ed.]: Preussischen Geol. Landesanstalt, Abh., new ser. $114,246 \mathrm{p}$.

Lombardi, O. W., 1963, Observations on the distribution of chemical elements in the terrestrial saline deposits of Saline Valley, California: U.S. Naval Ordnance Test Station NOTS TP 2916, $41 \mathrm{p}$.

Mason, B. H., 1958, Principles of geochemistry [2d ed.]: New York, John Wiley \& Sons, 310 p.

Meinzer, O. E., 1917, Geology and water resources of Big Smoky, Clayton, and Alkali Spring Valleys, Nevada: U.S. Geol. Survey Water-Supply Paper 423, 167 p.

Myers, A. T., Havens, R. G., and Dunton, P. J., 1961, A spectrochemical method for the semiquantitative analysis of rocks, minerals, and ores: U.S. Geol. Survey Bull. 1084-I, p. 207-229.

Parker, R. L., 1967, Composition of the Earth's crust, Chap. D, in Data of geochemistry [6th ed.]: U.S. Geol. Survey Prof. Paper 440-D, $19 \mathrm{p}$.

Pistrang, M. A., and Kunkel, Fred, 1958, A brief geologic and hydrologic reconnaissance of the Furnace Creek Wash area, Death Valley National Monument, California: U.S. Geol. Survey open-file report, $63 \mathrm{p}$.

Puccini, Giuliano, 1957, Stimulant action of lithium salts on the flower production of the perpetual carnation of the Riviera [in Italian, with English summary]: Ann. Sper. Agrar. (Rome), v. 11, p. 41-63.

Rankama, Kalervo, and Sahama, T. G., 1950, Geochemistry: Chicago Univ. Press, $912 \mathrm{p}$.

Robinson, W. O., Steinkoenig, L. A., and Miller, C. F., 1917, The relation of some of the rarer elements in soils and plants: U.S. Dept. Agriculture Bull. 600, 27 p.

Ronov, A. B., Migdisov, A. A., Voskresenskaya, N. T., and Korzina, G. A., 1970, Geochemistry of lithium in the sedimentary cycle [in Russian]: Geokhimiya, 1970, no. 2, p. 131-161; translated in Geochemistry Internat., v. 7, no. 2, p. 75-102, 1970.

Schoff, S. L., and Moore, J. E., 1964, Chemistry and movement of ground water, Nevada Test Site: U.S. Geol. Survey open-file report.

Schou, M., 1959, Lithium in psychiatric therapy-Stock-taking after ten years: Psychopharmacologia, v. 1, p. 65-78.

Shawe, D. R., Mountjoy, Wayne, and Duke, Walter, 1964, Lithium associated with beryllium in rhyolitic tuff at Spor Mountain, western Juab County, Utah, in Geological Survey research 1964: U.S. Geol. Survey Prof. Paper 501-C, p. C86-C87.

Sievers, M. L., and Cannon, H. L., 1974, Disease patterns of Pima 
Indians of the Gila Indian Reservation of Arizona in relation to the geochemical environment, in Hemphill, D. D., ed., Univ. Missouri Symposium on Trace Elements in Environmental Health, v. 7, p. 57-61.

Steinkoenig, L. A., 1915, Lithium in soils: Indus. and Eng. Chemistry Jour., v. 7, no. 5, p. 425-426.

Stewart, F. H., 1963, Marine evaporites, Chap. Y, in Data of geochemistry [6th ed.]: U.S. Geol. Survey Prof. Paper 440-Y, 52 p.

Stose, G. W., assisted by Ljungstedt, O. A., 1932, Geologic map of the United States: U.S. Geol. Survey, scale 1:2,500,000 [reprinted 1960].

Strock, L. W., 1936, Zur Geochemie des Lithiums: Nachr. Ges. Wiss. Gottingen Math.-Phys. Kl., IV, N. F. 1, no. 15, p. 171-204.

Swaine, D. J., 1955, The trace-element content of soils: [England] Commonwealth Bur. Soil Sci. Teeh. Comm. 48.

Tardy, Yves, Krempp, Gérard, and Trauth, Norbert, 1972, Le lithium dans les mineraux argileaux des sediments et des sols [Lithium in clay minerals of sediments and soils] [in French]: Geochim. et Cosmochim. Acta, v. 36, no. 4, p. 397-412.

Vinogradov, A. P., 1952, Fundamental laws of the distribution of trace elements among plants and environment, in Mikroelementy v zhizni Rastennii i Zhivotnykh-Mikroelement Konf., 1950 [in Russian]: Akad. Nauk SSSR Trudy, p. 7-20.

Vlasiuk, P. A., and Okhrimenko, M. F., 1967, On biological paradoxical phenomena [in Russian]: Acad. Sci. Ukranian, RSR Kiev,
Ser. Geology, Geophysics, Chemistry, and Biology, 1969, no. 4, UDK 581.1:581.143; English translation in Acad. Agr. Sci. Rept. 10, V. I. Lenin All-Union (Order of Lenin), Kolas Publisher.

1969, The effect of lithium on photochemical activity of chloroplasts of tomato and pepper leaves [in Russian]: Acad. Sci. Ukranian, RSR Kiev, Ser. Geology, Geophysics, Chemistry, and Biology, no. 4, UDK 581.132:546.34.

Voelcker, J. A., 1912, Pot-culture experiments: Royal Agr. Soc. Journ., England, v. 73, p. 314-338.

Voors, A. W., 1971, Minerals in the municipal water and atherosclerotic heart death: Am. Jour. Epidemiology, v. 93, p. 259-266.

Walker, G. E., and Eakin, T. E., 1963, Geology and ground water of Amargosa Desert, Nevada-California: Nevada Dept. Conserv. and Nat. Resources, Ground-Water Resources-Reconn. Ser. Rept. $14,58 \mathrm{p}$.

Wallace, A., Romney, E. M., and Hale, V. Q., 1973, Sodium relations in desert plants-[Pt.] 1. Cation contents of some plant species from the Mojave and Great Basin deserts: Soil Sci., v. 115, no. 4, p. 284-287.

Ward, F. N., Nakagawa, H. M., Harms, T. F., and VanSickle, G. H., 1969, Atomic-absorption methods of analysis useful in geochemical exploration: U.S. Geol. Survey Bull. 1289, 45 p.

Winograd, I. J., 1962, Interbasin movement of ground water at the Nevada Test Site: U.S. Geol. Survey open-file report, 11 p. 
$"$ 